\title{
Zaman ve Mekân Kesitinde Sınırötesi Mirasların, Dünya Mirası ile Karşılaştırmalı Analizi
}

\author{
A Comparative Analysis of Transboundary Heritages with World \\ Heritage cross Time and Space
}

\section{Seval Cömertler}

Dr. Şehir Plancısı

\section{ÖZ}

Sınırötesi miraslar Dünya Miras Listesi'nde (DML) birden çok devletin paydaş olduğu doğal, kültürel ya da karma nitelikli miras alanlarıdır. Dünya Mirasının (DM) uluslararası işbirliği ile korunmasını temel gaye edinen Dünya Miras Sözleşmesi'nin en net tezahürlerinden biri olarak kabul edilen bu miraslar biyolojik ve kültürel çeşitliliğin korunmasında, devletlerarasındaki ilişkilerin ve ortaklıkların geliştirilmesinde, çatışma çözümünde ve barışın tesisinde yanı sıra sürdürülebilir kalkınmada önemli bir role sahiptir. Bu çalışmanın amacı koruma ve planlamada özel bir boyut olan sınırötesi mirasların gelişimini zaman ve mekân kesitinde DM geneli ile karşılaştırmalı olarak incelemek ve bu sahada yapılacak yeni çalışmalar için öneriler geliştirmektir. Araştırma DML'ye girmiş bütün sınırötesi mirasları kapsamaktadır. Çalışmada, öncelikle kavramsal ve kuramsal altyapı sunulmuş ve önceki çalışmalar gözden geçirilmiştir. Ardından, sınırötesi miras alanları miras sayısı ve güvenliği, listelenme yılı, miras türü, paydaş devlet sayısı ve bölge değişkenlerine göre analiz edilmiştir. Değişkenlere ilişkin veriler Dünya Miras Merkezi'nden temin edilmiş olup, verilere betimleyici istatistik analiz teknikleri uygulanmıştır. Bulgular sınırötesi mirasların çok geniş bir çeşitlilik sunduğunu, ayrıca sınırötesi miras listesinin miras sayısı, türü ve paydaşlık ilişkileri bağlamında belirgin zamansal ve mekânsal farklılıklar içerdiğini ve bu durumun DML geneli ile kısmen örtüştüğünü kısmen de ayrıştığını ortaya koymuştur. Zaman kesitinde, sınırötesi miras listesinin 3 önemli dönüm noktası bulunmaktadır. Bu bağlamda, 1995 senesi miras sayısının düzenli ve ivmelenerek artmaya başladığı yıl, 2000 senesi türel dağılım oranlarının kültürel miraslar lehine değişmeye başladığı yıl, 2005 senesi ise konumlanış ve paydaşlık ilişkilerinin dönüşmeye başladığı yıldır. Fakat bu tarihler DM geneli için bir dönüm noktası değildir.

\section{ABSTRACT}

Transboundary heritages are natural, cultural or mixed heritage sites in World Heritage List (WHL), where multiple states are stakeholders. Considered as one of the clearest manifestations of World Heritage Convention, which aims to protect World Heritage $(\mathrm{WH})$ through international co-operation, these legacies have an important role in protection of biological and cultural diversity, in development of relations and cooperations between states, in conflict resolution and peace building, as well as in achieving sustainable development. This study aimed to examine development of transboundary heritages in comparison with $\mathrm{WH}$ in time and space and to develop recommendations for new studies. Research covered all transboundary heritages sites. In the study, firstly conceptual and theoretical background was presented and previous studies were reviewed. Subsequently, transboundary heritages were analyzed in terms of number and type of heritage, number of stakeholder states and region variables. Data on variables were obtained from World Heritage Center and descriptive statistical analysis techniques were applied to data. Findings revealed that transboundary heritages offered a wide variety, and transboundary heritage list contained significant temporal and spatial differences in terms of number, type of heritage and stakeholder relations. This situation partially overlapped with WHL and partially dissociated. In time section, there were 3 important milestones. In this context, 1995 was year when number of heritages started to increase, 2000 was year when generic distribution rates began to change in favor of cultural heritages, and 2005 was year when positioning and stakeholder relations began to transform. But these dates were not a turning point for WHL. In spatial section, there were

Geliş tarihi: 20.02.2018 Kabul tarihi: 22.05.2020

Online yayımlanma tarihi: 08.10.2020

Iletişim: Seval Cömertler

e-posta: sevalcomertler@gmail.com 
Mekân kesitinde ise hem DM genelinin hem de sınırötesi mirasların bölgelere dağılımında nicel ve türel dengesizlikler vardır. Bu dengesizlikte belirleyici bölge köklü bir planlama geleneğine ve koruma bilincine sahip Avrupa'dır. Zira DM'nin yarısı, sınırötesi mirasların yarıdan fazlası ve sınırötesi kültürel mirasların neredeyse tamamı Avrupa-Kuzey Amerika bölgesinde yer almaktadır. Ayrıca, sınırötesi miras sahibi devletlerin yarıdan fazlası Avrupa'dadır. Öte yandan, DML'de Türkiye'den hiç bir sınırötesi miras bulunmamaktadır. Bu bağlamda, Türkiye'nin sınırötesi miras potansiyeli incelenmeli, Mimar Sinan eserlerinin sınırötesi kültürel miras varlığı olarak DML'ye eklenmesi yönünde çalışmalar gerçekleştirilmelidir.

Anahtar sözcükler: Dünya mirası; Dünya Miras Listesi; sınırötesi miraslar; tarihi ve doğal çevre koruma. quantitative and generic imbalances in distribution of both $\mathrm{WH}$ and transboundary heritages. Determinative region in this imbalance was Europe, which had a long tradition of planning, and conservation awareness. Because half of $\mathrm{WH}$, more than half of transboundary heritages and almost all of transboundary cultural heritages were located in Euro-North America region. Further, more than half of stakeholder states were in Europe. Whereas, there was not any transboundary heritages from Turkey. In this context, Turkey's potential should be investigated, and Mimar Sinan's works should be listed as transboundary cultural assets in WHL.

Keywords: World heritage; World Heritage List; transboundary heritages; historical and natural environment conservation.

\section{Giriş}

Tek yapı ölçeğindeki koruma uygulamalarının tarihi çok eski zamanlara kadar uzanmakla birlikte, korumanın belirli ilkeler çerçevesinde ve bilimsel yöntemlerle gerçekleştirilmesi' 19. asırda başlayan, 193I'deki Atina Konferansı ve hemen akabinde İtalya'da kabul edilen Carta del Restauro (Restorasyon Tüzüğü) ile hızlanan bir gelişmedir (Ahunbay, 20II). Dünya Mirasının (DM) uluslararası bir çatı altında korunması fikri ise görece daha yeni bir düşüncedir.

İnsanlığın ortak mirası olan DM olağanüstü evrensel değere sahip kültürel ve doğal alanlar olup, bu alanların korunması tüm ulusların ortak sorumluluğudur. Uluslarası çatı ve ortak sorumluluk görüşü, I. Dünya Savaşının meydana getirdiği tahribattan etkilenerek başlamış ve II. Dünya Savaşı'nda kentlerde meydana gelen büyük ölçekli yıkımlar ve beraberinde yaşanan değişimler sonrasında gelişmiştir. Bu çerçevede, 1946 yılında UNESCO (United Nations Education Science Culture Organization) Birleşmiş Milletler'in özel bir kurumu olarak kurulmuş, 1954 yılına gelindiğinde ise silahlı çatışma halinde kültürel varlıkların korunmasına dair ilkelerin düzenlendiği Hague Convention (Lahey Sözleşmesi) kabul edilmiştir. Uluslararası çatı fikri 1959 yılında Abu Simbel Tapınağı'nın Aswan Barajı nedeniyle taşınmak durumunda kalmasıyla somutlaşmış, bu çerçevede milyonlarca dolar yardımın toplandığı uluslararası kampanyalar yürütülmüş, bir yandan da koruma çalışmalarını yönlendirici nitelikte yeni düzenleme arayışlarına gidilmiştir
(Altınöz, 20I2a; Dinçer, 20I2). Bu çerçevede, eski yapıların korunması ve onarımıyla ilgili ilkeler üzerinde karar vermek ve bunları uluslararası bir temele yerleştirmek amacıyla, 1964'te Venedik Tüzüğü olarak bilenen önemli kararlar alınmıştır. Venedik Tüzüğü koruma alanına önemli açılımlar getirmiştir. Bu bağlamda, anıt kavramı tek yapı ölçeğinden kentsel ya da kırsal yerleşme boyutuna kadar ulaşabilen geniş bir çerçeveye oturtulmuş, ayrıca kavram yalnızca büyük sanat eserlerini değil kültürel anlam kazanmış basit eserleri de içerecek şekilde genişletilmiş, böylece anıtların tarihi belge olarak korunması yaklaşımı ortaya çıkmıştır (Ahunbay, 20II).

$50^{\prime} l i$ ve $60^{\prime} l ı$ yıllarda kültürel mirasın korunmasına yönelik kabul edilen hukuki metinler ve yürütülen kampanyaların sonucunda, taslak metni ICOMOS (International Council on Monuments and Sites) tarafından hazırlanan Dünya Miras Sözleşmesi (DMS), UNESCO'nun 16 Kasım 1972 tarihli toplantısında Dünya Kültürel ve Doğal Mirasının Korunması Hakkında Sözleşme adıyla kabul edilmiștir (UNESCO, 1972). Temel misyonu üstün evrensel değere sahip kültürel ve doğal alanların korunması ve gelecek nesillere aktarılması olan bu sözleşme ile önceleri kültürel miraslara odaklanan koruma bilinci doğal varlıkları da içerecek şekilde genişletilmiş, kültürel ve doğal varlıkların korunmalarına ilişkin hedef ve kavramlar bir başlık altında toplanmış ve bu iki koruma alanı birbiriyle ilişkilendirilmiştir. ${ }^{2}$ Ayrıca, bu süreçte DM'nin korunmasına yönelik öncelikli amaçlar belirlenmiştir. Bunlar: ülkeleri DMS'yi imzalamaya teşvik etmek, kültürel ve doğal mirasların korunmasını sağla-

Düşünsel kökeni Avrupa'da başlayan bu gelişmenin aşamaları, alan yazında şu şekilde özetlenmektedir: İlk aşamada, Fransa, İngiltere ve İtalya'da üslup birliğine varış kaygısıyla önemli birçok tarihi eser üzerinde onarımlar yapılmış, ancak gelişigüzel olarak nitelendirilen bu çalışmalar tartışmalara yol açmışır. Akabinde, üslup birliğ yaklaşımına tepki olarak romantik görüş ileri sürülmüştür. Hiç restorasyon yapılmamasını öneren romantik görüş de koruma sorunlarının çözümünde yetersiz kalınca, I9. asrın sonlarına doğru, stilistik rekomposizyonun egemenliğine ve romantik görüşün pasif savunma ve kaderciliğine karșı biri tarihi restorasyon, diğeri çağdaş restorasyon olmak üzere iki önemli kuram ortaya çıkmıştır. Bu süreçte, Camillo Boito farklı koruma yaklaşımlarının parçalı ve tartışılan yönlerini uzlaştırıp, birleştirmeyi başarmış, 20. asırda Gustava Giovannoni'nin katkılarıyla Boito'nun belirlediği koruma ilkeleri uluslararası düzeyde kabul görmüş ve yayılmıştır. 1932 yılına gelindiğinde, bu ilkeler Carta del Restauro adıyla yasal bir kimlik kazanmıştır (ayrıntılı bilgi için bkz. Ahunbay, 20II).

Dünya Miras Sözleşmesinin kabul edilmesinden sonra da, kültürel ve doğal miras alanlarını korumaya yönelik birçok yasal düzenleme yapılmıştır. İçeriği zenginleşen bu düzenlemeler dünyada ve Türkiye'de koruma anlayışının ve politikalarının gelişiminde önemli bir rol üstlenmiștir. Amsterdam Bildirgesi- I975, Tarihi Alanların Korunması ve Çağdaş Rolleri Konusunda Tavsiyeler-1976, Göçmen Hayvan Türlerinin Korunması Sözleşmesi- 1983, Tarihi Kentlerin ve Kentsel Alanların Korunması Tüzüğü (Washington Tüzüğü-1 987), Arkeolojik Mirasın Yönetimi-1990, Nara Özgünlük Belgesi-1994, Sualtı Kültür Mirasının Korunması ve Yönetimi ile İlgili Tüzük-I 996, Nesli Tehlike Altında Olan Yabani Hayvan ve Bitki Türlerinin Uluslararası Ticaretine İlişkin Sözleşme-1996, Tarihi Ahşap Yapıların Korunması İçin İlkeler-1999, Geleneksel Mimari Miras Tüzüğü-1999, Mimari Mirasın Analizi, Korunması ve Strüktürel Restorasyonu İçin İlkeler-2003, Uluslararası Bitki Koruma Sözleșmesi-2005, Gıda ve Tarım için Bitki Genetik Kaynakları Uluslararası Sözleşmesi-2006 bu düzenlemelerin en önemlileridir. DM’nin korunmasına ilişkin uluslararası belgeler ve sözleşmeler hakkında ayrıntılı bilgi için bkz. Altınöz, 2012b; Ahunbay, 201।. 
mak; Sözleşme'ye Taraf Devletleri kendi ulusal sınırları içinde bulunan sit alanlarını Dünya Mirası Listesine (DML) aday göstermeye teşvik etmek; Taraf Devletleri, kendi DM sit alanlarının korunma durumuyla ilgili raporlama sistemleri kurmaya ve yönetim planları saptamaya teşvik etmek; teknik yardım ve profesyonel eğitim vererek Taraf Devletlerin DM varlıklarını korumalarına yardımcı olmak; yakın tehlike altında olan DM sit alanları için acil yardım sağlamak; DM'nin korunmasına yönelik Taraf Devletlerin kamuoyunu bilinçlendirme faaliyetlerini desteklemek; halkın kendi mirasının korunması faaliyetlerine katılımını teşvik etmek; dünyanın kültürel ve doğal mirasının korunmasında uluslararası işbirliğini teşvik etmek.

1978 yılına gelindiğinde, farklı ülkelerden 12 miras alanı ile DML uygulaması başlatılmıştır. DML'ye alınan bu sit alanları üstün evrensel değerde olup, ilk altısı kültürel, son dördü doğal miras ölçütü olmak üzere toplam on ölçütten en az birini karşılamaktadır. ${ }^{3}$ Bu ölçütlerden en az birini sağlayarak DML'ye giren miraslar 2019 yılı itibariyle I I 2 l'e ulaşmıştır (UNESCO, 2019a). Ancak 1978'den günümüze kadar olan süreçte, DML mirasların çeşitliliği ve bölgesel dağılımı bağlamında pekçok defa tartışılmıştır. Bu çerçevede 1994 yılında Küresel Strateji kabul edilmiş, böylece, güvenilir, dengeli ve temsili bir DML oluşturulması için tematik çeşitliliğinin arttırılması ve mirasların bölgesel dağılımında anlamlı bir dengenin oluşturulması amaçlanmıştır (WHC, 1994).

\section{I.I. Sınırötesi Miras Kavramı}

DML'ye giren miraslar tek bir üye devletin sınırları içinde olabildiği gibi, iki veya ikiden fazla devletin sınırları içinde de yer alabilmektedir. DML'de birden çok devletin sınırları içinde yer alan miraslar, sınırötesi (sınıraşan) miras (transboundary heritage) olarak isimlendirilmektedir. DMS'nin II. Maddesinin 3. Bendi uyarınca (UNESCO, 1972) ve bugüne kadar çeşitli defalar revize edilmiş olan Dünya Miras Sözleşmesinin Uygulanmasına Yönelik Operasyonel Kılavuzun 134., I35. ve I36. maddeleri uyarınca birden çok devletin sınırları içinde yer alan üstün evrensel değere sahip koruma alanları Taraf Devletlerin işbirliği ile sınırötesi miras olarak önerilebilmektedir (WHC, 2019). Bu yasal zeminde, günümüze değin farklı coğrafyalardan pek çok sınırötesi miras DML'ye eklenmiştir. ${ }^{4}$
Bugün, biyolojik ve kültürel çeşitliliğin korunmasında, çatışma çözümünde ve sürdürülebilir kalkınmada önemli bir role sahip olduğu görülen sınırötesi miraslar, gelecek nesiller için doğal ve kültürel miras alanlarının uluslararası işbirliği ile korunmasını temel gaye edinen DMS'nin en net tezahürlerinden biri olarak kabul edilmektedir (UNESCO, 2017). Zira Taraf Devletlerin işbirliğiyle gerçekleştirilen sınırötesi korumanın daha iyi yönetim, bütüncül yaklaşım ve bütünleşik planlama ile koruma çalışmalarında verimliliğin artması; bilimsel ve teknik işbirliklerinin gelişmesi; sürdürülebilir finansman mekanizmalarının tesisi ile iktisadi ortaklıkların kurulması; sosyal ve ekonomik kazanımların paylaşılması, bölgesel bütünleşme; barış inşası, güçlendirilmiş siyasi ilişkiler ve koruma çalışmalarına üst düzeyde geniş desteğin sağlanması gibi pek çok faydası bulunmaktadır (UNESCO, 2019d).

Sınırötesi mirasların yönetimi, korunması ve planlanması birden çok devletin sorumluluk ve yetki alanına girdiği için uluslararası işbirliğini, sınırötesi yönetişim ve planlama anlayışını da zorunlu kılmaktadır. Ancak, birçok nedenle sınırötesi mirasların ortak yönetimi karmaşık ve zorlayıcıdır, ${ }^{5}$ bununla birlikte zenginleştirici ve geliştiricidir. Çünkü sınırötesi mirasların korunması ve yönetiminin doğasında varolan içsel zorluklar, aslında, farklı kültürel ve yasal çerçevelerin ve finansman yapılarının sentezi ile DM'nin daha iyi nasıl korunabileceği, izlenebileceği ve yönetilebileceğine ilişkin yeni yollar bulunması için bir fırsattır. Bu bağlamda, 2017 yılında düzenlenen ve UNESCO tarafından raporlaştırılan, Almanya ve paydaşlarının sınırötesi mirasların korunması ve yönetimine ilişkin tecrübelerinin paylaşıldığı konferansın tartışmaları ve sonuçları, sınırötesi miras alanlarının gerçek laboratuarlar olduğunu göstermektedir. Bu rapora göre, miras alanlarının ortaklaşa korunması sayesinde hangi yönetim sistemlerinin kalıcı olarak uygun, etkili olduğunu çıkarmak mümkün olacaktır (UNESCO, 20I7). Bu bağlamda, sınırötesi miraslar üzerine yürütülecek araştırmalar koruma alan yazınının gelişimine önemli katkılar sağlayacaktır.

\section{I.2. Araştırmanın Amacı ve Kapsamı}

Bu araştırmanın amacı, zaman ve mekân kesitinde sınırötesi mirasların gelişimini DM geneli ile karşılaştırmalı olarak incele-

\footnotetext{
3 Dinçer'in (2012) çalışmasında bu ölçütler şu şekilde sıralanmaktadır: İnsan dehasının bir başyapıtını temsil etmek; bir zaman diliminde ya da dünyadaki bir kültürel alanda mimarlık, teknoloji, anıtsal sanat, kent planlama, peyzaj tasarımı konularında meydana gelen gelişmeleri, önemli bir dönüm noktası olarak sergilemek; kültürel bir geleneğin veya yaşayan ya da ortadan kalkmış bir medeniyetin tanıklığını üstlenmek; insanlık tarihinde önemli aşamaları gösteren yapı tipi, mimari veya teknolojik bütünlük veya peyzajın seçkin bir örneği olmak; çevre, kültür ve insan etkileşimini temsil etmek, ya da geri dönüşü olmayan değişimin etkisi altında savunmasız hale gelen geleneksel insan yerleşimlerinin, arazi kullanımının, ya da deniz kullanımının seçkin bir örneği olmak; olaylar veya yaşayan gelenekler, fikirler, sanatsal ve edebi eserler ile doğrudan veya somut olarak ilişkili, olağanüstü evrensel öneme sahip olmak; mükemmel doğa olayları veya istisnai doğal güzelliği ve estetik önemi olan alanları içermek; devam eden önemli jeolojik süreçler ya da önemli jeomorfolojik veya fizyografik özellikler dahil olmak üzere dünya tarihinin önemli aşamalarını temsil eden seçkin örnekler olmak; evrim süreci içinde devam eden temel ekolojik ve biyolojik süreçleri ve karasal, tatlı su, kıyı ve deniz ekosistemleri ile bitki ve hayvan topluluklarının gelişiminin seçkin örneklerini temsil etmek; son olarak, bilim veya koruma açısından olağanüstü evrensel değer taşıyan tehlike altındaki türler de dahil olmak üzere, biyolojik çeşitliliğin yerinde korunması için en önemli ve en özellikli doğal yaşam alanlarını içermek.

4 Bir kentin, bir bölgenin ve hatta bir ülkenin siyasi sınırlarını aşan, birden çok devletin sınırları içinde yer alan doğal, kültürel ya da karma nitelikli bu miraslar hakkında ayrıntılı bilgi için bkz. UNESCO, 2019c.

5 Geniş alana yayılan sınırötesi mirasların korunması daha fazla kaynak ve zaman ayrılmasını, yanı sıra daha fazla hazırık ve genişletilmiş taahhütler verilmesini (hem adaylık aşamasında hem de sonrasında) gerektirmektedir. UNESCO'ya göre (20I9d), bu faktörler sınırötesi işbirliklerinin kurulmasında ve sürdürülmesinde karşılaşılan önemli güçlüklerdir.
} 
mektir. Böyle bir amaç doğrultusunda, bu çalışmada, sınırötesi mirasların DML içindeki yerini anlamak, sınırötesi miraslar için kurulan uluslararası işbirliklerinin zaman ve mekân kesitindeki gelişimini ortaya koymak, bu bağlamda, sınırötesi miras listesi ile DML geneli arasındaki benzerlik ve farklılıkları tespit etmek, sınırötesi miraslar üzerine yürütülmüş önceki araştırmaları gözden geçirmek ve ülkemizde bu sahada yapılacak yeni çalışmalar için öneriler geliştirmek hedeflenmiştir. Bu amaç ve hedefler doğrultusunda araştırmanın temel soruları ve alt soruları aşă̆ıdaki gibi belirlenmiştir:

- Sınırötesi mirasların DML'deki payı nedir? Bu alanlar nasıl bir çeşitlilik sunmaktadır? Türkiye'nin sınırötesi miras listesindeki yeri nedir?

- Sınırötesi miras listesi "ZAMAN" kesitinde nasıl bir gelişim göstermiştir? Bu gelişimin DML geneli ile benzerlik ve farklılıkları nelerdir?

- Sınırötesi mirasların tarihsel süreç içinde listelenme seyri nasıl gelişmiştir? Bu mirasların listelenmesinde belirgin dönüm noktaları var mıdır? Varsa nelerdir? Bu bağlamda DML geneli ile benzerlikler/farkllıklar nelerdir?

- Sını̈ötesi mirasların DML'ye eklenmesinde doğal/kültürel miras eğilimi var mıdır? Türel dağııım bağlamında zamansal farklılıklar var mıdır? Türel dağııım özellikleri DML ile ne tür benzerlikler/farkllıklar göstermektedir?

- Sınırötesi mirasların Taraf Devletlere dağııımı ne şekildedir? Sınırötesi miraslar-paydaşlık ilişkisinde zamansal farklılıklar var midır?

- Sınırötesi miras listesi "MEKÂN" kesitinde nasıl bir gelişim göstermiştir? Bu gelişimin DML geneli ile benzerlik ve farklılıkları nelerdir?

- Sınırötesi mirasların listelenmesinde mekânsal farklılıklar var mıdır? Bu mirasların devletlere ve bölgelere dağııımı dengeli midir? Coğrafı dağııımı DML ile ne tür benzerlikler / farklılıklar göstermektedir?

- Sınıötesi mirasların türel dağılımında mekânsal farklılıklar var mıdır? Bu bağlamda DML geneli ile benzerlikler /farklılıklar nelerdir?

- Sınıötesi miraslar-paydaşlık ilişkisinde mekânsal farklılıklar var midır?

Araştırma evrenini, üstün evrensel değere sahip koruma alanlarının listenmeye başlandığı 1978 ylından günümüze değin DML'ye girmiş bütün sınırötesi miras alanları oluşturmakta olup, araştırma holistik bir ele alışla, bunların tamamını kapsamaktadır.

\section{I.3. Yöntem ve Organizasyon}

Araştırma yöntemi, temel olarak, ilgili alan yazının incelenmesi ve UNESCO Dünya Miras Merkezinin (DMM) sunduğu veri- ler kullanılarak gerçekleştirilen betimleyici istatistik analizlere dayanmakta olup, makale dört ana başık altında organize edilmiştir. Bu çerçevede, ilk olarak, çalışmanın kavramsal ve kuramsal altyapısını ortaya koymak üzere koruma olgusu, DM ve tarihsel süreç içinde DM'nin uluslararası bir çatı altında korunması fikrinin gelişimi, DML ve sınıötesi miras kavramı açıklanmış, ardından, araştırmanın amacı, kapsamı, soruları, yöntem ve organizasyonu ortaya konulmuştur. Önceki çalışmaların gözden geçirildiği ikinci başlık altında, sınırötesi koruma alanlarına ve sınırötesi miraslara ilişkin alan yazın incelenmiştir. $^{6}$

Üçüncü aşamada, sınırötesi mirasların zaman ve mekân kesitindeki gelişimini DM geneli ile karşılaştırmalı olarak sunan niceliksel analiz bulguları tablo, harita ve fotoğraflarla desteklenerek açıklanmış ve tartışılmıştır. Analizlere konu olan değişkenler miras sayısı ve güvenliği, listelenme yılı, genişleme durumu, miras türü, paydaş devlet sayısı, paydaş devletlerin miras sayısı ve bölge değişkenleri olup, bu değişkenlere ilişkin veriler DMM'nin resmi internet sitesinden temin edilmiştir. Verilere betimleyici istatistik analiz teknikleri uygulanmıştır. Bu çerçevede, toplam değer, ortalama değer, en yüksek değer, en düşük değer, sıralama ve frekanslar incelenmiş, çapraz tablolamalar yapılmıştır. Analiz bulgularının ortaya konulduğu bu bölüm, araştırma sorularına paralel bir biçimde üç alt başlık içermektedir. Birinci alt başlıkta, öncelikle, DM'nin tarihsel süreç içindeki gelişimine ve mirasların bölgesel-türel dağılımına ilişkin analiz bulguları aktarılmış, ardından sınırötesi mirasların DML içindeki payı ve çeşitliliği ortaya konulmuştur. Ayrıca, bu alt başılıta, Türkiye'nin DML'deki sınırötesi miras payı ve potansiyeli üzerine değerlendirmeler yapılmıştır. Sonrasında, sınırötesi mirasların tarihsel süreç içinde DML'deki gelişimine, türel dağılımına ve paydaşlık ilişkilerine ait bulgular ortaya konulmuş ve DM geneli ile karşılaştırmalı olarak tartışılmışır. Üçüncü başlıkda, sınırötesi mirasların mekân kesitindeki dağıIımı DM geneli ile karşılaştırmalı olarak sunulmuş ve tartışımıştır. Sonuç kısmında, bütün bulgular bir matris yardımıyla özetlenmiş ve değerlendirilmiş, ayrıca, Türkiye'nin sınırötesi miras potansiyelinin değerlendirilmesine ilişkin politika ve araştırma önerileri ortaya konulmuştur.

\section{Alan Yazında Sınırötesi Koruma Alanları ve Sınırötesi Miraslar}

Doğal kaynakların ve çevrenin sınırötesi işbirlikleri ile korunması üzerine bilimsel araştırmalar ve çalışmalar $70^{\prime} l i$ yıllara kadar uzanmakla birlikte (bkz. Carroll, 1979; Rüster ve Simma, 1975), bu araştırmaların belirli bir ivme kazanması 90'lı yılların sonlarına doğru gerçekleşmiştir. Örneğin, Stolton ve Dudley (1999), Zbicz (1999a, 1999b), IUCN/WCPA

\footnotetext{
6 Alanyazındaki araştırmaların içeriğine ilişkin ayrıntılı inceleme ve değerlendirmelerin başlı başına ayrı bir araştırmayı gerektirecek genişlikte olduğu düşüncesiyle, bu makale kapsamında, önceki araştırmaların odaklandığı meseleleri ana hatlarıyla ortaya koyan bir tarama gerçekleştirilmiştir.

7 Her ne kadar DML ilk defa 1978'de oluşturulmaya başlanmışsa da sınırötesi koruma faaliyetlerinin geçmişi daha önceki yıllara uzanmaktadır. Dolayısıyla, alan yazındaki ilk çalışmalar 1978'den önce başlamış olup, bu çalışmalar, ilerleyen süreçte, sınırötesi miras araştırmalarına öncülük etmiş ve temel oluşturmuştur.
} 
(1998), Westing (1998), Danby (1997), Hamilton (1996), Mcneely (1995), Thorsell ve Harrison'un (1990) çalışmaları 90'lı yıllarda alan yazına giren araştırmaların yalnızca bir kısmını oluşturmaktadır. Bu öncü çalışmalarda, genel olarak, sınırötesi korumanın doğası, ortaklaşa yönetim, sınırötesi koruma alanlarının ve barış parklarının çatışma çözümüne ve barışa katkısı, çeşitli sınıö̈tesi koruma alanlarına ilişkin tecrübeler, kazanımlar, fırsatlar, kısıtlayıcılıklar ve sınırötesi koruma alanlarının sağladığı faydalar ele alınmıştır. Ayrıca, bir yandan, sınırötesi koruma alanlarının daha iyi yönetimi için stratejiler ve uluslararası ortaklık imkânları, diğer yandan, uluslararası ortaklıkların geliştirilmesi için sınırötesi koruma alanlarının araçsallığı gibi çift yönlü meseleler bu dönemdeki araştırmaların diğer konularını oluşturmuştur.

2000 'li yıllara gelindiğinde ise, gerek devlet kurumlarının gerekse de araştırmacıların hem sınırötesi koruma alanlarına ilgisinde bir artış yaşanmış hem de sınırötesi miraslara ilişkin ilk araştırmalar alan yazına girmeye başlamıştır. Bu çerçevede, sınırötesi miraslar UNESCO raporlarında ve çeşitli bilimsel çalışmalarda ele alınmış (örneğin bkz. UNESCO, 2017; Svels ve Sande, 2016; Albrecht, 2010), ayrıca, DML'ye henüz eklenmemiş, ancak birçok devletin sınırları içinde bulunan sulak alanlar, nehirler, barış parkları, mimari miras vd. sınırötesi kültürel ve doğa koruma alanları üzerine pek çok araştırma yürütülmüş ve lisansüstü tezleri hazırlanmıştır. Bu araştırmalarda sınırötesi koruma alanlarının planlanması ve yönetiminde güvenlik boyutu (Braack vd., 2006), sınırötesi koruma alanlarının turizm vasıtasıyla gerçekleşen ekonomik katkıları (Bushell ve Eagles, 2007) yanı sıra bu alanların ekolojik faydaları (McCallum vd., 2014), mimari mirasın korunmasına ilişkin geliştirilen sınırötesi işbirlikleri (Wongwaiwit, 2009), Avrupa ülkelerinin sınırötesi koruma tecrübeleri (Vasilijević ve Pezold, 20 II; Haapala, 2003), sınırötesi korumada karşılaşılan fırsatlar ve güçlükler (Vasilijević, 20I2), farklı sınırötesi koruma modelleri (Church, 20I2) ortaya konulmuştur. Sınırötesi koruma alanlarının barışın tesisine ve çatışma çözümüne katkısı ise, $2000^{\prime} l i$ yıllarda da yine bir çok araştırmaya konu olmuştur (Pouya vd., 2017; Ali, 2010; Philips vd., 2006; Alsdirawi ve Faraj, 2004; Sandwith vd., 200I). Ayrıca, bu dönemde, Afrika kıtası sınırötesi koruma çalışmaları bağlamında araştırmacılar için adeta bir laboratuvar olmuştur. Zira 2000'li yılların başında, Biyolojik Çeşitliliği Destekleme Programı çerçevesinde, bütün Afrika kıtasındaki doğa ve kaynak koruma alanları Batı Afrika (Biodiversity Support Program, $200 \mathrm{la}$ ), Doğu Afrika (Biodiversity Support Program, 200 lb) ve diğer bölgeler olmak üzere kısım kısım çalışılmış ve birden çok ülkenin sınırları içinde yer alan doğa koruma alanlarının ve kaynakların yönetimine ilişkin planlar geliştirilmiş, raporlar hazırlanmış, çalıştay ve sempozyumlar düzenlenmiştir (Braack vd., 2003). Son yıllarda ise, Afrika'daki sınırötesi koruma alanlarına ilişkin hak ve kazanımların yerel topluluklara dağııımı tartışılmaktadır (Chifamba, 20।2).
Sınırötesi koruma alanyazınının ivmelenerek geliştiği 2000'li yıllarda, devletlerin sınırötesi işbirliği kurma girişimleri de artmıştır. Bu bağlamda, güncel araştırmalar içinde, Vasilijević vd.'nin (20I5) "Sınırötesi Koruma: Sistematik ve Entegre Bir Yaklaşım" isimli çalışması, doğal ve kültürel kaynakların birden çok devletin işbirliği ile korunmasına yönelik girişimlere rehber olması niteliği ile öne çıkmaktadır. Bu çalışmada, öncelikle farklılaşan sınırötesi koruma alanlarının bir tipolojisi ortaya konulmuş, ardından, sınırötesi koruma girişimleri için geliştirilen öneriler dünyadaki farklı bölgelerden çok sayıda en iyi uygulama örnekleri ile aktarılmışır.

Sınırötesi koruma alanlarının DML'de kendilerine daha çok yer bulmaları sonucunda, 2000'li yıllarda, doğrudan sınırötesi mirasları konu alan çalışmalar da gerçekleştirilmiştir. Örneğin, Danby ve Slocombe $(2005,2002)$ DML'ye ilk giren sınırötesi miraslardan biri olan buzullar bölgesi St. Elias'ı ekosistem coğrafyası, bölgesel ekoloji ve devletler arası işbirliği çerçevesinde incelemiştir. Albrecht (2010) ve Armaitienè (2007) ise geleneksel yerleşmelere evsahipliği yapan Kuron Kıyı Oku üzerine araştırmalarda bulunmuşlardır. Armaitienè (2007), sınırötesi mirasların sürdürülebilir kalkınma ve turizm sektörüne katkısı bağlamında, Kuron Kıyı Oku'nu turizm gelişimi ve entegre kıyı şeridi yönetimi açısından ele almışırı. Aynı sınırötesi mirası inceleyen Albrecht (2010) ise sözkonusu alanın korunmasının önündeki engellerin kaldırıması ve işbirliğinin geliştirilmesi için devletler düzeyindeki çabaların artırılması ve yerel toplulukların eksiksiz desteklenmesinin gereğine işaret etmiştir. Albrecht (20l0), ayrıca, belirli bir takım çevresel ve sınırötesi yönetişim ilkelerine uyularak, sınırötesi miras alanlarının korunması ve yönetiminde çatışmaların önüne geçilebileceğini ve daha iyi sonuçlar elde edilebileceğini belirtmiştir.

Güncel bazı çalışmalar ise sınırötesi mirasların korunması ve yönetiminden dersler çıkarmaya, uluslararası tecrübeden öğrenmeye yönelmiştir. Örneğin, UNESCO'nun yayınladığı bir raporda (2017), Almanya'nın doğal ve kültürel mirasların korunması için kurduğu uluslararası işbirliklerinden edindiği tecrübeler paylaşılmıştır. Almanya ve paydaşlarının doğanın ve kültürün korunmasındaki farklı yaklaşımlarına ve koruma mekanizmalarına yer veren rapor, Almanya'nın DML'de yeralan bütün sınırötesi miraslarını kapsamaktadır. Uluslararası tecrübeden öğrenmeyi vurgulayan bir başka güncel sınırötesi miras araştırmasında ise, Svels ve Sande (2016) İskandinavya'dan iki örnek vermektedir. İlk örnek, Norveç-İsveç sınırlarında yeralan Laponia doğal-kültürel miras alanıdır. Diğeri ise, morenli takımadalar olarak bilinen, İsveç-Finlandiya sınırları içindeki High Coast/Kvarken doğal miras alanıdır. Svels ve Sande (20I6) araştırmalarında, İskandinav ülkelerinin güçlü bir sınırötesi öğrenme geleneği sergilediğini ve sınırötesi koruma alanlarına ilişkin problemlerin sınırötesi öğrenme yoluyla aşılabileceğini önermişlerdir. 
Özetle, uluslararası alanyazında, doğrudan sınırötesi miraslar üzerine gerçekleştirilen bu öncü araştırmalarda, daha çok, sınırötesi mirasların etkili bir şekilde korunması ve yönetilmesi için devletlerarası işbirliğine, yerel toplulukların desteklenmesine ve sınırötesi mirasların korunması ve yönetiminden çıkarılabilecek derslere odaklanılmıştır. Türkiye'de ise koruma ve planlama alanındaki öne çıkan dergiler ve diğer bilimsel çalışmalar incelendiğinde, kültürel ve doğal mirasın korunması üzerine geniş bir alan yazın oluştuğu görülmekte (örneğin, bkz. Ulusan ve Yıldırım, 2016; Altınöz, 20I2a, 20I2b, 20I2c; Kuban, 20I2; Ahunbay, 20I I; Dinçer vd., 20II; Tekeli, 20II; Güçhan ve Kurul, 2009; Özdemir, 2005; Tankut, 2005), ancak, sınırötesi koruma araştırmaları bağlamında çok az sayıda yayın tespit edilebilmektedir. Bu bağlamda, Demireş Özkul ve Pouya (2017) ile Pouya vd.'nin (2017) barış parklarını konu alan araştırmaları bu yayınlara örnek teşkil etmektedir. Doğrudan sınırötesi mirasların incelenmesi bağlamında ise alan yazınımızın gelişmesi gerekmektedir.

\section{Bulgular ve Tartışma}

\section{I. UNESCO Dünya Mirası, Sınırötesi Miraslar ve Türkiye}

İlk defa 1978 yılında uluslararası bir çatı altında DML'ye giren doğal ve kültürel koruma alanları, yılda ortalama 26,69 yeni miras alanının listeye eklenmesiyle, 2019 yilında toplam 167 ülkede $1|2|$ adede $^{8}$ ulaşmıştır (Tablo I). Hâlihazırda, DML'deki varlıkların 869'u kültürel miras, 2/3'ü doğal miras, 39'u karma mirastır (UNESCO, 2019b).

Tablo I'deki veriler incelendiğinde (1979, 1989, 1997, 1999, 2000 yılları gibi uç değer gösteren bazı yıllar hariç), mirasların listelenmesinde miktara ve miras türüne göre belirgin dönemsel farklılıklar görülmemektedir. Bu bağlamda, kültürel veya doğal öneme sahip varlıklar, günümüze kadar düzenli bir seyir ile DML'ye eklenmiştir. Ancak, DM'nin türel dağılımı dengeli değildir. Zira DML'nin ilk yıllarından günümüze kadar, kültürel miraslar istikrarlı bir şekilde ve ortalama $\% 77,52$ oranla ağırılıklı bir paya sahip olmuştur. Ayrıca, DM'nin bölgelere ve üye devletlere dağılımında da dönemsel olmayan dengesizlikler bulunmaktadır (Tablo 2 ve Şekil I). Örneğin, 2019 yılı itibariyle, DML'de en çok mirası olan İtalya, Çin, İspanya, Almanya ve Fransa DM'nin toplam \%22,2l'ine sahiptir. Miras sayılarına göre ilk 20 devlet içinde yer alan 9 Avrupa ülkesi ise 292 varlık ile DM'nin \%26'sına sahiptir. DM'nin yarıdan fazlası (\%53,52'si) yalnızca 20 devlet (bütün üye devletlerin $\% 10,36$ 'sı) tarafından paylaşılmaktadır (bkz. Tablo 2). Bununla birlikte, DMM resmi istatistiklerine göre, UNESCO'ya üye 193 ülkeden 37'sinin DML'de yalnızca I adet varlığı bulun-
Tablo I. DML'nin tarihsel süreç içinde gelişimi

\begin{tabular}{|c|c|c|c|c|}
\hline \multirow[t]{2}{*}{ YII } & \multicolumn{4}{|c|}{ Miras sayısı } \\
\hline & Kültürel & Doğal & Karma & Toplam \\
\hline 1978 & 8 & 4 & 0 & 12 \\
\hline 1979 & 34 & 8 & 3 & 45 \\
\hline 1980 & 22 & 5 & 0 & 27 \\
\hline $198 \mid$ & 15 & 9 & 2 & 26 \\
\hline 1982 & 17 & 5 & 2 & 24 \\
\hline 1983 & 19 & 9 & I & 29 \\
\hline 1984 & 15 & 7 & 0 & 22 \\
\hline 1985 & 25 & 4 & I & 30 \\
\hline 1986 & 23 & 5 & I & 29 \\
\hline 1987 & 32 & 7 & 2 & 41 \\
\hline 1988 & 19 & 5 & 3 & 27 \\
\hline 1989 & 4 & 2 & I & 7 \\
\hline 1990 & 11 & 2 & 3 & 16 \\
\hline |991 & 16 & 6 & 0 & 22 \\
\hline 1992 & 16 & 4 & 0 & 20 \\
\hline 1993 & 29 & 4 & 0 & 33 \\
\hline 1994 & 21 & $7^{*}$ & 0 & $28 *$ \\
\hline 1995 & 23 & 6 & 0 & 29 \\
\hline 1996 & 30 & 5 & 2 & 37 \\
\hline 1997 & 38 & 7 & I & 46 \\
\hline 1998 & 27 & 3 & 0 & 30 \\
\hline 1999 & 35 & 11 & 2 & 48 \\
\hline 2000 & 50 & 10 & 1 & 61 \\
\hline 2001 & 25 & 6 & 0 & 31 \\
\hline 2002 & 8 & 0 & 1 & 9 \\
\hline 2003 & 19 & 5 & 0 & 24 \\
\hline 2004 & $28^{*}$ & 5 & 0 & $33^{*}$ \\
\hline 2005 & 17 & 7 & 0 & 24 \\
\hline 2006 & 16 & 2 & 0 & 18 \\
\hline 2007 & 16 & 5 & I & 22 \\
\hline 2008 & 19 & 8 & 0 & 27 \\
\hline 2009 & II & 2 & 0 & 13 \\
\hline 2010 & 15 & 5 & I & 21 \\
\hline 2011 & 21 & 3 & I & 25 \\
\hline 2012 & 20 & 5 & I & 26 \\
\hline 2013 & 14 & 5 & 0 & 19 \\
\hline 2014 & 21 & 4 & 1 & 26 \\
\hline 2015 & 23 & 0 & I & 24 \\
\hline 2016 & 12 & 6 & 3 & 21 \\
\hline 2017 & 18 & 3 & 0 & 21 \\
\hline 2018 & 13 & 3 & 3 & 19 \\
\hline 2019 & 24 & 4 & I & 29 \\
\hline
\end{tabular}

*: Liste dışı bırakılan miraslar çıkarıldıktan sonraki durumu göstermektedir Toplam miras sayısı: II2I (\%77,52'si kültürel miras, \%19,00'u doğal miras, \%3,48'i karma miras). Risk altındaki miras sayısı: 53 (\%4,23). Kaynak: DMM resmi istatistiklerinden yararlanılarak oluşturulmuştur.

8 Bugüne kadar toplam II 23 varlık DML'ye eklenmiş olmakla birlikte, daha önce Tehlike Altındaki Dünya Mirası Listesi'nde bulunan 2 miras (Arabian Oryx Sanctuary doğa mirası ve Dersden Elbe Vadisi kültürel mirası) gerekli koruma önlemleri alınmadığı için liste dışı bırakılmıştır (UNESCO, 20।9a). 
Tablo 2. DML'de en çok mirası bulunan devletler

\begin{tabular}{|c|c|c|c|c|c|c|c|}
\hline Sira & Ülke & Miras sayısı & DML'deki oranı (\%) & Sira & Ülke & Miras sayısı & DML'deki oranı (\%) \\
\hline 1 & İtalya & 55 & 4,91 & 11 & İran & 24 & 2,14 \\
\hline 2 & Çin & 55 & 4,91 & 12 & Japonya & 23 & 2,05 \\
\hline 3 & İspanya & 48 & 4,28 & 13 & Brezilya & 22 & 1,96 \\
\hline 4 & Almanya & 46 & 4,10 & 14 & Avustralya & 20 & $\mathrm{I}, 78$ \\
\hline 5 & Fransa & 45 & 4,01 & 15 & Kanada & 20 & 1,78 \\
\hline 6 & Hindistan & 38 & 3,39 & 16 & Türkiye & 18 & $\mathrm{I}, 6 \mathrm{I}$ \\
\hline 7 & Meksika & 35 & 3,12 & 17 & Yunanistan & 18 & $I, 6 I$ \\
\hline 8 & Birleşik Krallık & 32 & 2,85 & 18 & Portekiz & 17 & $\mathrm{I}, 52$ \\
\hline 9 & Rusya Federasyonu & 29 & 2,59 & 18 & Polonya & 16 & $\mathrm{I}, 43$ \\
\hline \multirow[t]{2}{*}{10} & A.B.D. & 24 & 2,14 & 20 & İsveç & 15 & $\mathrm{I}, 34$ \\
\hline & Toplam & 407 & 36,30 & & Genel toplam & 600 & 53,52 \\
\hline
\end{tabular}

DMM resmi istatistiklerinden yararlanılarak oluşturulmuştur.

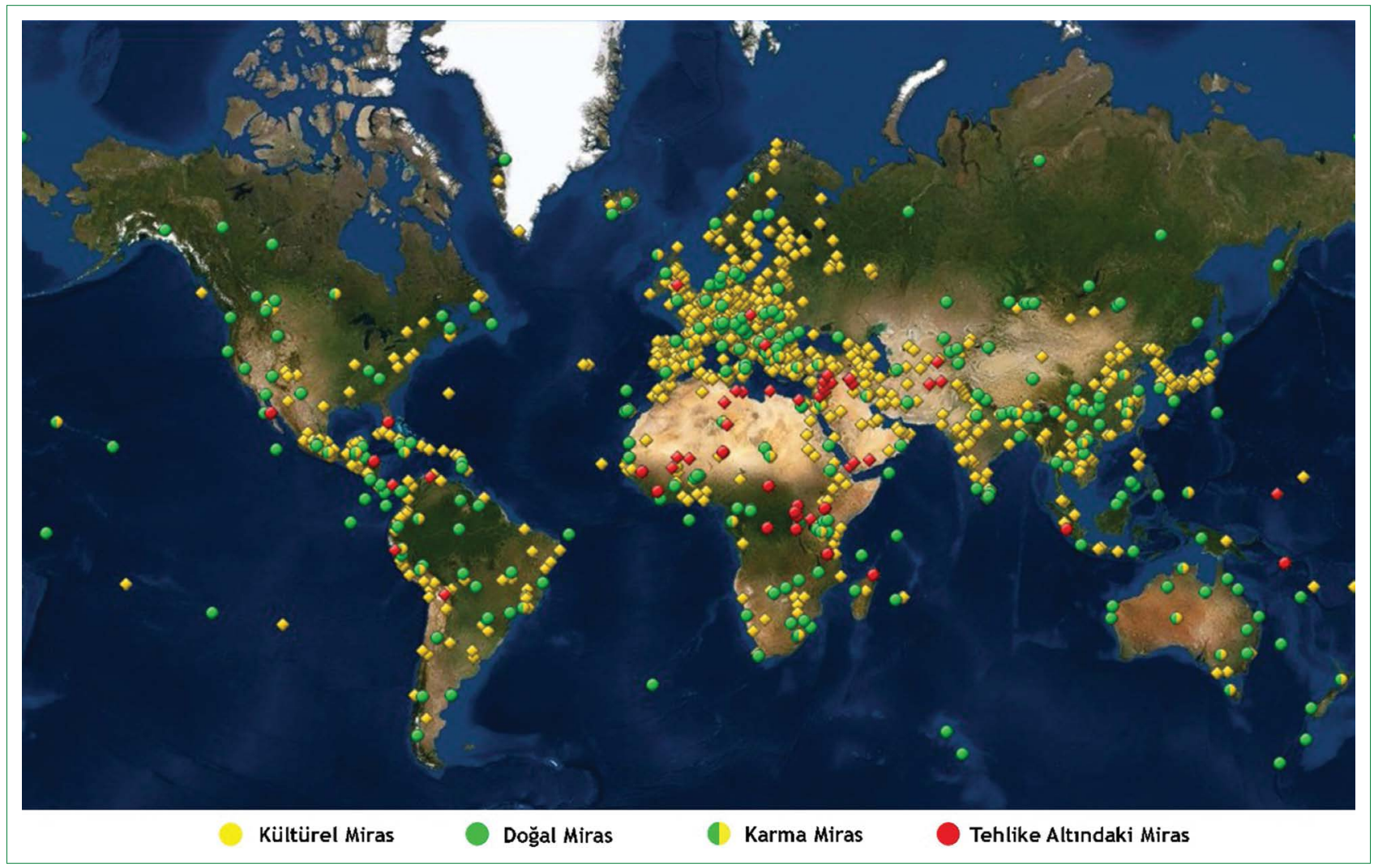

Şekil I. DM'nin mekânsal dağıımı (UNESCO, 2019a).

makta, 26 devletin ise hiçbir doğal ya da kültürel miras varlığı yer almamaktadır (UNESCO, 20l9b).

Şekil I'deki harita incelendiğinde, DM'nin bölgesel dağılımındaki dengesizlik açıkça görülmektedir. Bu bağlamda, Avrupa kıtası çarpıcı bir farkla DML'deki varlıkların önemli bir bölümüne sahip iken Afrika ve Arap ülkeleri bölgesel sıralamada geridedir. Bütün bu bulgular, 1994'te geliştirilen Küresel Stra- teji kapsamında alınan dengeli ve temsili bir liste kararına rağmen, hali hazırda DML'deki mirasların türel ve bölgesel dağılımında dengenin sağlanamadığını göstermektedir.

Öte yandan, miras sahipliliği bağlamında bölgesel sıralamada geride kalan Afrika ve Arap ülkeleri, ne yazık ki, mirasların korunması noktasında da geridedir (Şekil I). Zira bugün, birçoğu yoksulluk, çatışma ve iç savaşların yaşandığı Afrika 


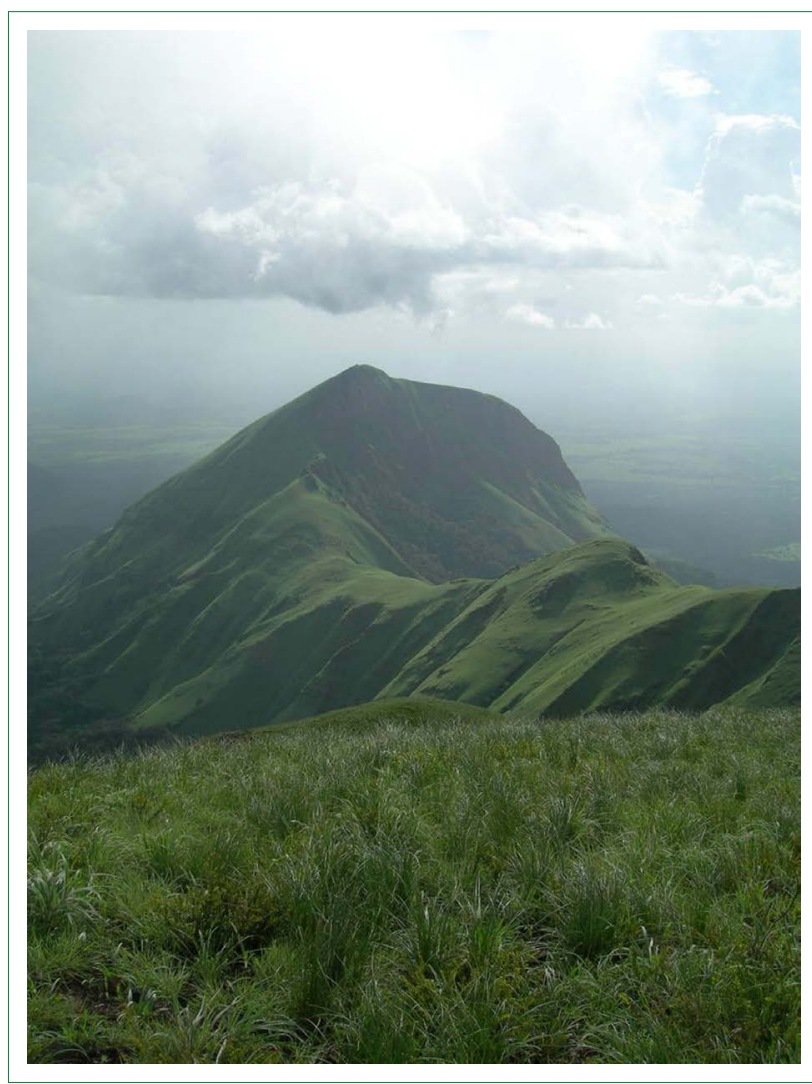

Şekil 2. Nimba Dağı tehlike altındaki tek sını̈ötesi mirastır (UNESCO, 2019c).

ve Arap ülkelerinde olmak üzere, DML'deki 53 miras doğal afetler, savaş durumu, kentsel gelişme, tarımsal faaliyetler ve turizm baskıları gibi nedenlerle risk altındadır (Ulusan ve Yıldırım, 2016). ${ }^{9}$

Tehlike altındaki DM varlıklarından biri Fildişi Sahili ve Gine sınırları içinde yer alan Nimba Dağı Mutlak Koruma Alanı'dır (Şekil 2). DML'ye ilk giren sınırötesi miraslardan olan ve yaklaşık 20.000 hektarlık bir alanı kaplayan Nimba Dağı koruma alanındaki flora ve fauna, civar yerleşmelerdeki nüfusun tarım, hayvancilık ve avcllık faaliyetleri nedeniyle uzun bir süredir risk altındadır. Bununla birlikte, günümüzde, sürdürülebilir kalkınma anlayışı çerçevesinde tehlike altındaki bu mirasları korumak için uluslararası işbirliklerini geliştirme bilinci ve çabası da artmaktadır. Örneğin, 2019'da Nimba Dağı vd. sınırötesi miraslarla ilişkili olarak, Afrika'da sürdürülebilir kalkınma ve barış için sınırötesi miras alanlarının korunmasına yönelik "Afrika'daki Dünya Miras Alanlarının Etkili Yönetimi İçin Sınırötesi İşbirliği" konulu ilk bölgesel toplantı yapılmıştır. Gine,
Fildişi Sahili, Benin, Burkino Faso, Nijer, Kongo, Kameron vd. sınırötesi miras sahibi ülkelerin ve 40 kuruluşun iştirak ettiği; çıktılarının raporlaştırıı yayınlanması planlanan bu toplantının Afrika halkları arasında bölgesel bütünleşmenin teşviki, yoksulluğun azaltılması, sosyal uyumun güçlendirilmesi, sürdürülebilir kalkınma ve inovasyonun geliştirilmesi ve barışın tesisine yönelik çalışmalara katkı yapması beklenmektedir (UNESCO, 2019a).

DML, Nimba Dağı mutlak koruma alanının yanı sıra, 67 ülkenin sınırları içinde çok çeşitli doğal ve kültürel varlıkların oluşturduğu zengin bir sınırötesi miras portföyü sunmaktadır. Bu mirasların isimleri, listelenme yılları, miras türleri, içinde yer aldıkları bölge ve ülkeler DMM'nin resmi internet sitesinden yararlanılarak oluşturulan Tablo 3'te sunulmaktadır (Tablo 3'teki veriler kullanılarak yürütülen analizlere ilişkin bulgular ilerleyen başlıklar altında ayrıntılı olarak ortaya konulmakta ve tartışılmaktadır). Tablo 3 incelendiğinde, sınırötesi mirasların kadim kayın ormanlarından tarihi kent merkezlerine, dünyanın en görkemli şelalelerinden kalker taşından yapılmış ortaçağ mezartaşlarına ve mezarlıklarına, steplerden tarih öncesi kaya resimlerine, kanyonlardan kazıklı evlere, buzullardan tropikal orman ekosistemlerine, nirengi zincirinden ulusal parklara, Cizvit yerleşmelerinden karstik mağaralara, biyolojik çeşitlilik açısından dünya ölçeğinde son derece önemli, kritik role sahip kıyı sulak alanlarından çan kulelerine, morenli takımadalardan zengin flora ve faunaya sahip sıradağlara, tarihi demiryollarından ipek yoluna, taş çemberlerden peyzaj parklarına, savunma yapılarından dünyanın ilk uluslararası barış parkına, civa madenlerinden ahşap kiliselere, arkeolojik sit alanlarından modern mimarlı̆ı̆ başyapıtlarına kadar uzanan çok geniş bir çeşitliliğe sahip olduğu görülmektedir.

Bu zengin sınırötesi miras portföyündeki varlıklar, 2019 yılı itibarıyla toplam 39 adede ulaşmış olup, bunların yalnızca bir tanesi (bütün sınırötesi mirasların \%2,50'si) risk altındadır. Sınırötesi mirasların DML içindeki payı \%3,48'dir. UNESCO'ya üye bütün devletlerin içinde sınırötesi mirası olanların oranı \%35, DML'de miras varlığı bulunan devletler içinde sınırötesi mirası olanların oranı \% 40'dır. 126 üye devletin ise sınırötesi mirası yoktur. Bu devletlerden biri, DMS'ye 1983 yilında taraf olan ve hali hazırda DML'de 2'si karma, 16'sı kültürel olmak üzere toplam 18 mirası bulunan Türkiye'dir. ${ }^{10}$

Ancak, Türkiye'nin DML'de hiçbir sınırötesi mirasının bulunmaması ilginç bir durumdur. Zira Türkiye medeniyetlerin beşiği olan ve birçok devlete ve imparatorluğa ev sahipliği yapmış,

9 UNESCO'nun 2019 yılı resmi istatistiklerine göre, risk altındaki mirasların \%39,62'si başta Suriye olmak üzere Yemen, Filistin vd. Arap ülkelerinde; \%30,19'u Afrika'da, \%।I,32'si Latin Amerika ülkelerinde, bir diğer \% I I,32'si Asya-Pasifik bölgesinde yer almaktadır. Avrupa-Kuzey Amerika Bölgesi tehlike altındaki mirasların en az sayıda olduğu coğrafyadır. Bu bölgede tehlike altında olan 4 adet miras $(\% 7,55)$ bulunmaktadır (UNESCO, 20I9b).

10 Türkiye'nin DML'deki mirasları Göreme Milli Parkı ve kayalık Kapadokya kenti, İstanbul'un tarihi alanları, Divriği Ulu Cami ve Şifahanesi, Hattuşaş, Nemrut Dağı, Hierapolis-Pamukkale, Xsanthos-Letoon antik kentleri, Safranbolu kenti, Truva arkeolojik kenti, Selimiye Camii ve Külliyesi, Çatalhöyük, Bursa ve Cumalıkızık, Bergama ve çok katmanlı kültürel peyzajı, Diyarbakır Surları ve Hevsel Bahçeleri, Efes, Ani arkeolojik sit alanı, Afrodisyas ve Göbekli Tepe'dir. Türkiye'nin DML'deki miras varlığı ve potansiyeli ile ilgili ayrıntılı bilgi ve tartışmalar için bkz. UNESCO, 2019a; Ulusan ve Yıldırım, 2016; Dinçer vd., 2011. 


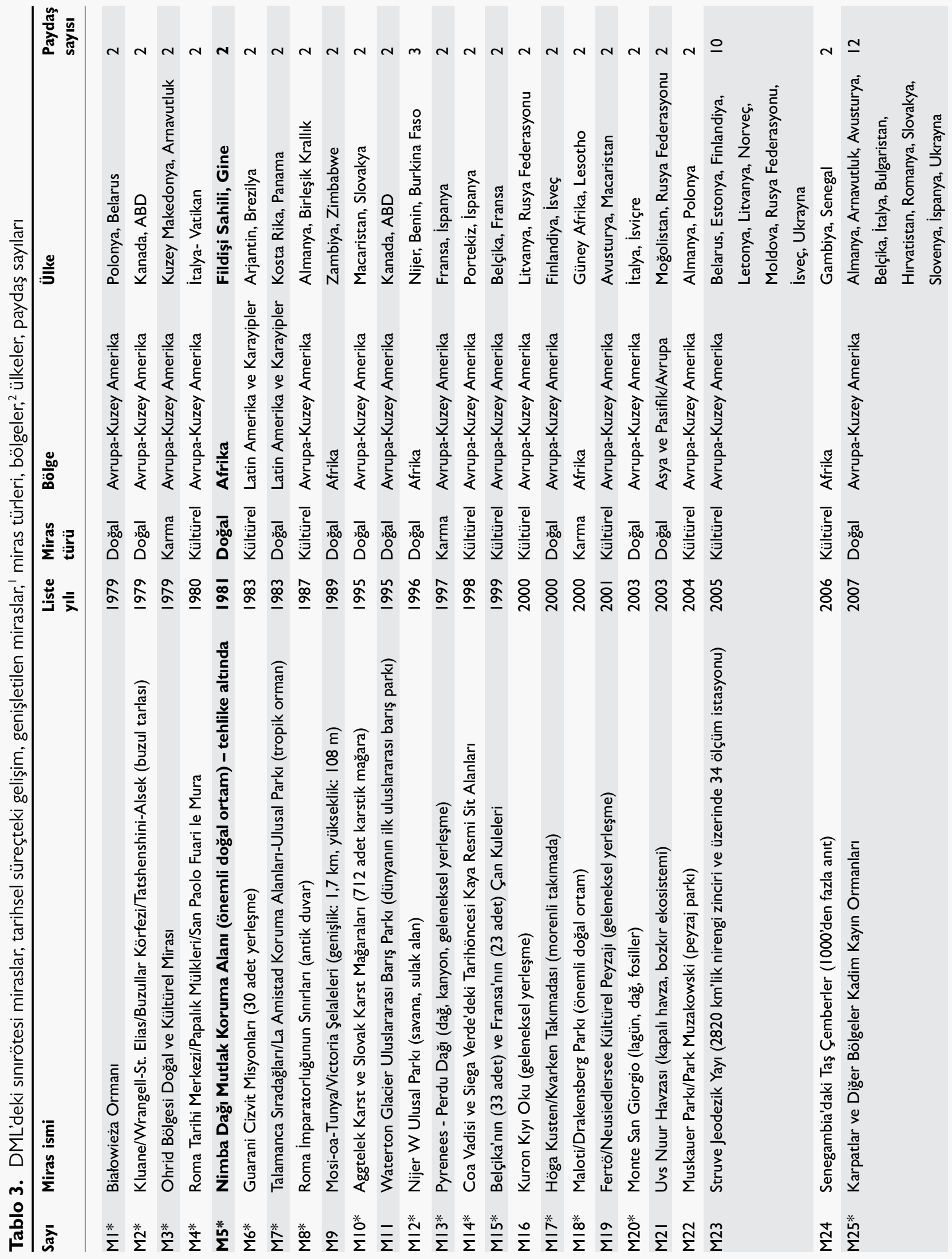




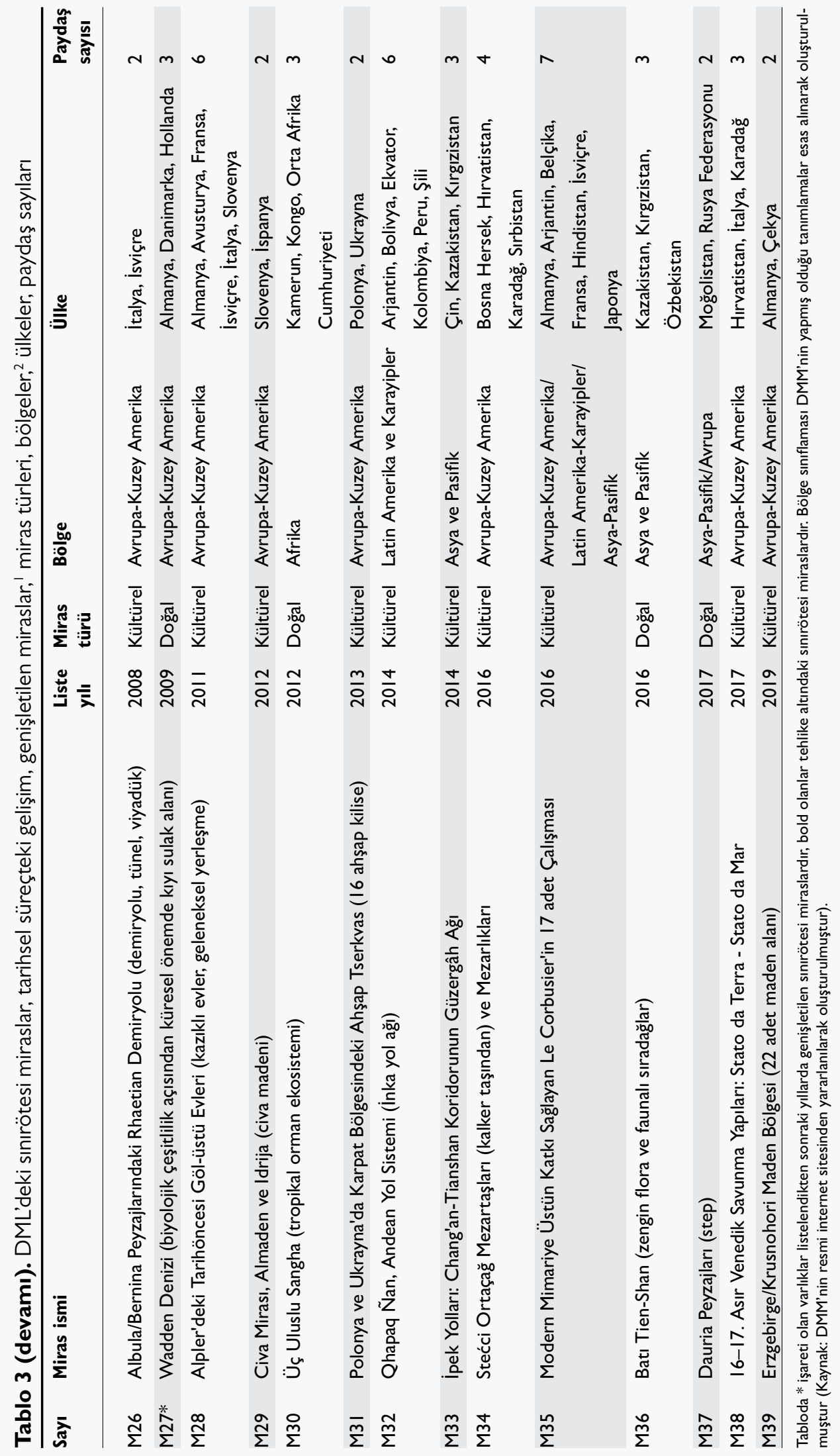


doğal ve kültürel zenginlikleriyle üç kıtanın kesiştiği Anadolu coğrafyası üzerinde yer almaktadır. Tarih öncesi ve sonrası dönemlerde, Anadolu ve yakın çevresi Troya, Hatti, Hitit, Hurri, Urartu, Frigya, Lidya, Helen, Karya ve Likya uygarlıklarına, Roma ve Bizans İmparatorluğuna, Selçuklu Devletine, OsmanIı İmparatorluğuna ev sahipliği yapmış kadim bir coğrafyadır (Anadolu uygarlıkları, kültür tarihi ve kentleri hakkında bkz. Akurgal, 20I5; Gür, 2010). Bugün, Anadolu Türkiye Cumhuriyeti Devleti'ne, çevresi komşularına ev sahipliği yapmaktadır. Dolayısıyla Anadolu ve çevresi tarih boyunca üzerinde yaşayan toplumların, kurulan devletlerin ve kentlerin ürettiği zengin bir kültür mirasına sahiptir.

Örneğin, dört padişah görmüş Osmanlı'nın baş mimarı Sinan'ın tam sayısı kesin olarak bilinememekle birlikte," bir bölümü artık yokolmuş cami, mescit, medrese, han, hamam, saray, darüşşifa, imaret, türbe, mahzen, suyolu, bend, kemer, köprü gibi çeşitli işlev ve türlerdeki yapıları, başta İstanbul olmak üzere, Osmanlı İmparatorluğunun üç kıtadaki yayılma alanları içinde inşa edilmiştir (Mimar Sinan ve eserleri hakkında bkz. ÇEKÜL Sinan'a Saygı Projesi, 2019; Günay, 2014; Saatçi, 2014; Erzen, 2005; Aslanapa, 1988; Batur ve Batur, 1967; Tezkiretü'l-Ebniye ve Tezkiretü'l-Bünyan). Ancak, Osmanlı İmparatorluğunun yıkılmasıyla birlikte sınırlar yeniden çizilmiş, böylece Sinan'ın eserlerinin büyük bir bölümü Türkiye Cumhuriyeti topraklarında, bir bölümü ise Bosna-Hersek, Bulgaristan, Yunanistan, Kırım ve daha birçok devletin sınırları içinde kalmıştır (Alan yazındaki kaynaklar taranarak oluşturulan Tablo 4, Mimar Sinan'ın bugün Türkiye sınırları dışında kalan eserlerinin bir listesini sunmaktadır).

Zaman içinde Sinan'ın eserlerinin bir kısmı yıkılıp, yokolurken bir kısmı ayakta kalmayı başarmış, hatta DML'ye eklenmiştir. ${ }^{\prime 2}$ Bu yapılardan biri üzerine romanlar yazılan ve 2007'de DML'ye eklenen Drina Köprüsüdür (UNESCO, 2019a). Hâlihazırda, Türkiye sınırları içinde ve dışında, Sinan'ın İstanbul tarihi yarımadadaki eserleri, Edirne'deki Selimiye Cami ve Vişegrad'daki Drina Köprüsü (Şekil 3) DML'de yer almaktadır. Ancak bu yapılar ilgili ülkelerin işbirliği ile sınırötesi kültürel miras varlığı olarak UNESCO'ya sunulmuş değildir. Edirne ve İstanbul'dakiler Türkiye'nin miras varlığı, Vişegrad'daki Drina Köprüsü ise Bosna-Hersek'in miras varlığı olarak listede yer almaktadır. Sonuç olarak, Mimar Sinan'ın Türkiye sınırları içinde ve dışında yüzlerce eseri bulunmakla birlikte, bu yapılar sınırötesi miras varlığı olarak DML'de yer almamaktadır.

Mimar Sinan eserleri Türkiye'nin sınırötesi miras potansiyeli açısından bir örnektir. Ancak, elbetteki, Türkiye'nin sınırötesi miras potansiyelinin, yalnızca Mimar Sinan'ın eserleri ile
Tablo 4. Mimar Sinan'ın Türkiye sınırları dışındaki bilinen eserleri

\begin{tabular}{|c|c|c|}
\hline Ülke & Şehir & Eser \\
\hline Bosna & Bosna & Mehmet Paşa İmareti \\
\hline \multirow[t]{4}{*}{ Hersek } & & Mehmet Paşa Kervansarayı \\
\hline & & Mehmet Paşa Sarayı \\
\hline & Vişegrad & Sokullu Mehmet Paşa (Drina) Köprüsü \\
\hline & Mostar & Karagöz Mehmet Paşa (Bey) Cami \\
\hline \multirow[t]{2}{*}{ Bulgaristan } & Hasköy & Çoban Mustafa Paşa (Svilengrad) Köprüsü \\
\hline & Sofya & Bosnalı (Sofu) Mehmet Paşa Camisi \\
\hline \multirow[t]{4}{*}{ Filistin-İsrail } & Kudüs & Cami-i Şerif (Haseki) İmareti \\
\hline & & Cami \\
\hline & & Medrese \\
\hline & & Hürrem Sultan Hanı \\
\hline \multirow[t]{7}{*}{ Irak } & Bağdat & İmam-ı Azam Camisi \\
\hline & & Imam-ı A'zam Tekkesi \\
\hline & & Murat Paşa Camisi \\
\hline & & Şeyh Abdulkadir-i Geylâni Camisi \\
\hline & & Şeyh Abdülkadir-i Geylâni Tekkesi \\
\hline & Basra & Maktul Ayas Paşa Camisi \\
\hline & Kerkük & Sultan Süleyman (Gülenber Kalesi) Cami \\
\hline \multirow{3}{*}{$\begin{array}{l}\text { Kırım Özerk } \\
\text { Cumhuriyeti }\end{array}$} & Gözleve & Tatar Han Cami (Kezlev Camisi) \\
\hline & & Tatar Han Türbesi \\
\hline & Kefe & Sultan Süleyman Han Hamamı \\
\hline \multirow[t]{2}{*}{ Macaristan } & Budin & Mustafa Paşa Camisi \\
\hline & & Mustafa Paşa Türbesi \\
\hline \multirow[t]{9}{*}{ Suriye } & Halep & Adliye Camisi \\
\hline & & Hüsrev Paşa Camisi (Hüsreviye) \\
\hline & & Hüsrev Paşa İmareti \\
\hline & & Hüsrev Paşa Medresesi \\
\hline & Şam & Sultan Süleyman Han Cami \\
\hline & & Sultan Süleyman Han İmareti \\
\hline & & Sultan Süleyman Han Kervansarayı \\
\hline & & Sultan Süleyman Han Tabhanesi \\
\hline & & Haseki Sultan İmareti \\
\hline \multirow{6}{*}{$\begin{array}{l}\text { Sudi } \\
\text { Arabistan }\end{array}$} & Medine & Mehmet Paşa Hamamı \\
\hline & & Sultan Süleyman Han Hamamı \\
\hline & Mekke & Sultan Süleyman Han Medresesi \\
\hline & & Haseki Sultan İmareti \\
\hline & & Mehmet Paşa Hamamı \\
\hline & & Haremi Şerifin onarımı \\
\hline \multirow[t]{2}{*}{ Yunanistan } & Trikkala & Osman Şah Cami (Kurşunlu Cami) \\
\hline & (Tırhala) & Mehmet Bey (Rüstem Kethüdası) Camisi \\
\hline
\end{tabular}

" Mimar Sinan'ın eserlerinin sayısı hakkında farklı bilgilere ulaşılmaktadır. Örneğin, Günay (20।4) bu sayının 477 olduğunu belirtirken, Erzen’e (2005) göre, Mimar Sinan'ın eserlerinin sayısı 500'ün üzerindedir.

12 Bugün, Sinan'ın ayakta kalan eserlerinin bir bölümü asli fonksiyonuna uygun şekilde, diğerleri ise başka işlevler için kullanılmakta olup, bu yapıların içinde özgün durumları korunabilenlerin yanı sıra yanlış onarım ve değişikliklerle özgünlüğü kaybolmuş ya da bakımsızlık nedeniyle görünümü değişmiş olanlar da vardır. 

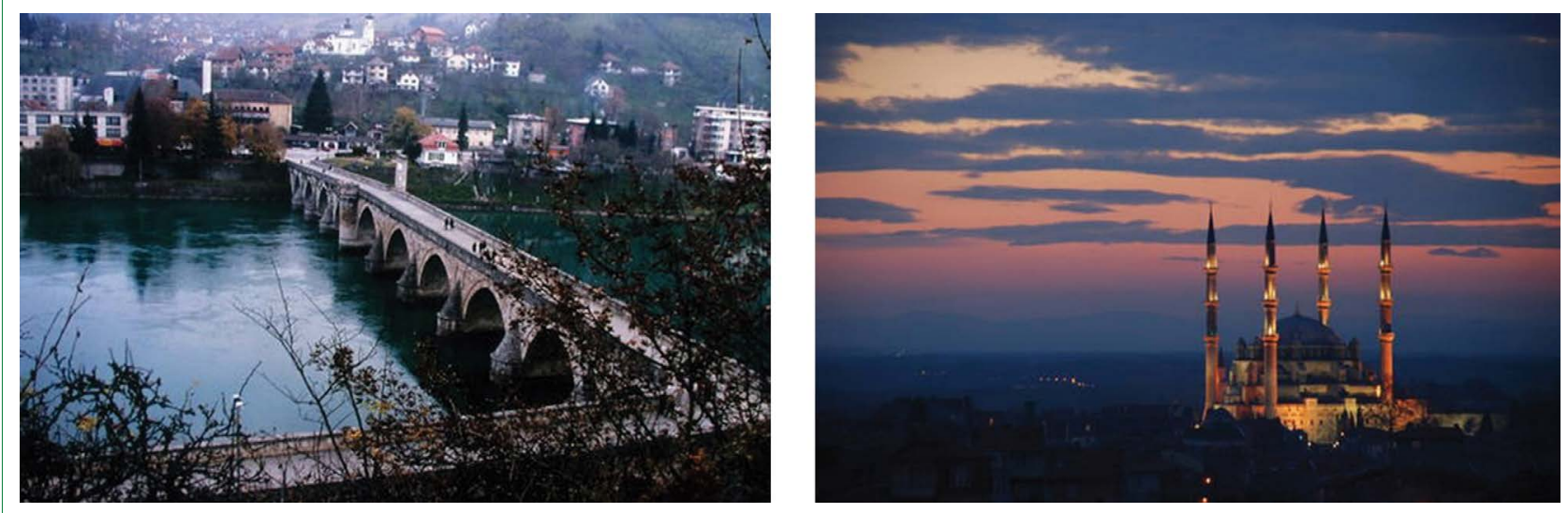

Şekil 3. Sokullu Mehmet Paşa Köprüsü, Vişegrad - Bosna Hersek (sol), Selimiye Cami, Edirne - Türkiye (sağ) (UNESCO, 20I 9a)

Tablo 5. Tarihsel süreçte sınırötesi mirasların listelenmesi ve genişleme durumu

\begin{tabular}{|c|c|c|c|c|c|c|c|}
\hline Listelenme tarihi & $\begin{array}{l}\text { Sınırötesi } \\
\text { miras } \\
\text { sayısı }\end{array}$ & $\begin{array}{c}\text { Sınırötesi } \\
\text { miras } \\
\text { listesindeki } \\
\text { oranı (\%) }\end{array}$ & $\begin{array}{l}\text { DM içindeki } \\
\text { sınırötesi } \\
\text { miras oranı } \\
\text { (\%) }\end{array}$ & $\begin{array}{c}\text { Her yıl } \\
\text { listelenen yeni } \\
\text { sınırötesi } \\
\text { miras sayısı } \\
\text { (ortalama) }\end{array}$ & $\begin{array}{c}\text { Her yıl } \\
\text { listelenen yeni } \\
\text { DM sayısı } \\
\text { (ortalama) }\end{array}$ & $\begin{array}{l}\text { Genişletilen } \\
\text { sınırötesi } \\
\text { miras sayısı }\end{array}$ & $\begin{array}{c}\text { Genişletilen } \\
\text { sınırötesi } \\
\text { mirasların } \\
\text { oranı (\%) }\end{array}$ \\
\hline 1995 öncesinde & 9 & 23,08 & 2,05 & 0,53 & 25,76 & 8 & 88,88 \\
\hline 1995 ve sonrasında & 30 & 76,92 & 4,39 & 1,20 & 27,32 & 10 & 33,33 \\
\hline 1978-2019 yılları toplamı & 39 & 100,00 & 3,48 & 0,95 & 26,69 & 18 & 46,15 \\
\hline
\end{tabular}

sınırlı olduğu düşünülemez. Bilakis, Orta Asya'daki köklerinden günümüzdeki vatanına kadar uzanan çok geniş bir coğrafyada pek çok uygarlıkla temas etmiş, bir arada olmuş, ilişki kurmuş, iç içe yaşamış bir ulusun, büyük bir doğal ve kültürel zenginliğe sahip kadim Anadolu coğrafyası üzerinde kurulu olan son devleti Türkiye Cumhuriyeti'nin sınırötesi miras potansiyelinin oldukça yüksek olduğu rahatlıkla düşünülebilir. ${ }^{13}$

\subsection{Zaman Kesitinde Sınırötesi Miraslar: Listelenme,}

Türel Dağııım, Paydaşlık

Sınırötesi mirasların listelenmesi, ilk defa, DML'nin ikinci yılında, 1979'da gerçekleşmiştir. Kluane/Saint Elias/Buzullar Körfezi, Białowieża Ormanı ve Ohrid Bölgesi DML'ye ilk giren sınırötesi miras alanları, Erzgebirge/Krusnohori Maden Bölgesi ise son giren sınırötesi mirastır. 1978-2019 yılları arasında, her yıl ortalama 0,95 yeni miras alanının listeye eklenmesiyle, sınırötesi miras sayısı bugün toplam 39 adede ulaşmıştır. 1979, 2000 ve 2016 yılları 3'er adet varlık ile DML'ye en çok sayıda sınırötesi mirasın dâhil olduğu yıllardır. I3'ü 1995 yılı̈ öncesinde olmak üzere, toplam 15 farklı senede ise hiç bir sınırötesi miras DML'ye eklenmemiştir.
Tablo I, Tablo 3 ve Tablo 5 birlikte incelendiğinde, DML'deki dönemsel farklılık göstermeyen düzenli genel büyüme eğiliminden farklı bir şekilde, sınırötesi mirasların ağırlıklı olarak 1995 yılından sonra ve artan bir seyir ile listelendiği görülmektedir. Tablo I ve Tablo 5'te görüldüğü üzere, DML'de her yıl listenen miras sayısı 1995 öncesi ve sonrasında önemli bir farklılık göstermemektedir. Ancak, 1995 öncesinde listelenen sınırötesi miras sayısı yılda ortalama 0,53 iken, 1995 sonrasında bu değer yılda ortalama I,20 mirasa yükselmiştir. Başka bir ifadeyle, sınırötesi mirasların \%23,08'i 1995'ten önceki yıllarda, \%76,92'si ise 1995'ten 2019'a kadar geçen süreçte DML'ye eklenmiştir. Böylece, sınırötesi mirasların 1995 öncesinde, DML'deki \%2,05 olan payı, 1995 ve sonrasındaki yıllarda 2 kat artarak \%4,39 olarak gerçekleşmiştir. Ayrıca, Viktorya Şelaleleri hariç, 1995 öncesinde listeye giren sınırötesi mirasların tamamı listelendikten sonraki yıllarda bir veya iki kez genişlemeye tabi tutulmuşlardır. Yanı sıra, 1995 sonrasında listelenenlerin de bir bölümü ilerleyen yıllarda genişlemeye tabi olmuşlardır (bkz. Tablo 3 ve Tablo 5). Bütün bu bulgular, son yıllarda, ülkelerin DM'nin korunması bağlamında sınırötesi işbirlikleri kurma çabalarının arttı̆̆ını, dolayısıyla sınırötesi mirasların DML'deki payının artmakta olduğunu açıkça göstermektedir.

${ }^{3}$ Ancak, potansiyel bütün örnekleri ortaya koymak başlı başına ayrı bir araştırmanın ya da pek çok araştırmanın konusu olabilecek genişlikte ve derinlikte bir meseledir. Dolayısıyla, sınırötesi miras olabilecek muhtemel bütün örnekleri açılamak bu çalışmanın amaçını ve kapsamını aşacağı için, burada meseleyi Sinan eserleri ile örneklemek yeterli görülmüştür. 
Tablo 6. Zaman kesitinde sınırötesi mirasların ve DM'nin türel dağıımı

\begin{tabular}{|c|c|c|c|c|c|}
\hline \multirow[t]{2}{*}{ Periyot } & \multirow[t]{2}{*}{ Miras türü } & \multicolumn{2}{|c|}{ Sınırötesi miraslar } & \multicolumn{2}{|c|}{ DM geneli } \\
\hline & & Sayı & Oran (\%) & Sayı & Oran (\%) \\
\hline \multirow[t]{4}{*}{2000 öncesinde (1978-1999) } & Doğal & 8 & 53,34 & 125 & 19,91 \\
\hline & Kültürel & 5 & 33,33 & 479 & 76,27 \\
\hline & Karma & 2 & 13,33 & 24 & 3,82 \\
\hline & Toplam & 15 & 100,00 & 628 & 100,00 \\
\hline \multirow[t]{4}{*}{2000 ve sonrasında $(2000-2019)$} & Doğal & 8 & 33,33 & 88 & 17,85 \\
\hline & Kültürel & 15 & 62,50 & 390 & 79,11 \\
\hline & Karma & 1 & 4,17 & 15 & 3,04 \\
\hline & Toplam & 24 & 100,00 & 493 & 100,00 \\
\hline \multirow[t]{4}{*}{ 1978-2019 yılları toplamı } & Doğal & 16 & $4 I, 03$ & 213 & 19,00 \\
\hline & Kültürel & 20 & 51,28 & 869 & 77,52 \\
\hline & Karma & 3 & 7,69 & 39 & 3,48 \\
\hline & Toplam & 39 & 100,00 & 1121 & 100,00 \\
\hline
\end{tabular}

Sınırötesi miraslar miras türlerine göre incelendiğinde, 2000'li yıllara kadar DM genelinden çok farklı ve tezat bir şekilde, sınırötesi doğal mirasların daha yüksek bir oranla $(\% 53,34)$ listelendiği tespit edilmiştir (bkz. Tablo I, Tablo 3 ve Tablo 6). Doğal miras varlığının ağırlıkta olduğu bu yıllarda, DML'ye sınırötesi kültürel miras olarak yalnızca 5 adet varlık girmiştir (bkz. Tablo 3). Ancak, 2000 ve sonrasındaki yıllarda listeye eklenen 15 yeni kültürel miras alanı, sınırötesi mirasların türel dağııım oranlarını önemli ölçüde değiştirmiştir. Bununla birlikte, aslında bu dönemdeki türel dağılım oranlarının da dengeli olduğunu söylemek mümkün değildir. Zira 2000-2019 döneminde listeye giren sınırötesi mirasların \%33,33'ü doğal, \%62,50'si kültürel, \%4, I7'si karma niteliklidir. Dolayısıyla, bu dönemde, kültürel mirasların lehine gelişen bir dengesizlik durumu sözkonusudur. 1978-2019 yılları bütününde ise, sınırötesi doğal miraslar bütün sınırötesi mirasların \%4I,03'ünü, kültürel miraslar 51,28'ini oluşturmaktadır. Karma miraslar ise $\% 7,69^{\prime}$ luk bir oranla temsil edilmekte olup, bu oran bütün karma mirasların DML'deki oranının üzerindedir.

Sonuç olarak, bu bulgular sınırötesi mirasların türel dağııımında 2000 yılı öncesi ve sonrası olmak üzere iki farklı dönem olduğunu, ancak her iki dönemde de türel dağıımın dengeli olmadığını; bu bağlamda, 2000 öncesindeki dengesizliğin doğal miraslar lehine, sonrasındaki dengesizliğin ise kültürel miraslar lehine gerçekleştiğini ortaya koymaktadır. Ancak, 2000 öncesinde doğal miraslar lehine gelişen dengesizlik, 2000'li yıllarda kültürel miraslar lehine gelişen dengesizlik ile dengelenmiş, böylece 1978-2019 yılları bütününde sınırötesi miraslar türel dağılım açısından görece anlamlı bir dengeye ulaşmıştır.
Tablo 6'da görüldüğü üzere, sınırötesi mirasların türel dağılımı ve bu dağııımın zaman kesitindeki seyri, kesinlikle DM genelinden farklıdır. Zira DM genelinde türel dağıım, DML'nin oluşturulmaya başlandığı 1978'den günümüze kadar kesintisiz bir şekilde kültürel miraslar lehine bir dengesizlik içermiştir ve hâlihazırda bu dengesizlik durumu devam etmektedir. Dolayısıyla, türel dağılım bağlamında, sınırötesi miras listesi 1994'te geliştirilen Küresel Strateji kapsamında alınan dengeli ve temsili bir miras listesi vizyonunu DM geneline kıyasla daha çok sağlamaktadır.

Sınırötesi miraslar paydaşlık bağlamında incelendiğinde ise, bu mirasların 27 tanesinin iki paydaşlı olduğu, 12 tanesinin ise ikiden fazla ülkenin sınırları içinde konumlandığı görülmektedir (bkz. Tablo 3). Birçok paydaşı olan mirasların yarısı üç ülkenin, diğer bir yarısı ise üçten fazla ülkenin sınırları içindedir. En çok sayıda paydaşı olan sınırötesi miras, Avrupa'nın kadim kayın ormanlarıdır. ${ }^{14} 2820$ km'lik bir nirengi zincirini ve bu zincirin üzerinde bulunan 34 adet ölçüm istasyonunu içeren Struve Jeodezik Yayı ise en çok sayıda devlet tarafından paylaşılan sınırötesi kültürel mirastır (Şekil 4). ${ }^{15}$

Sınırötesi mirasların listelenme seyri ve türel dağılımında tespit edilen zamansal farklılık, Tablo 3 ve Tablo 7 birlikte incelendiğinde, sınırötesi miraslara paydaşlık ve konumlanış bağlamında da görülmektedir. 2005 yılına kadar, DML'ye yalnızca birbirine komşu iki ülkenin sınırları içinde yer alan sınırötesi miraslar (Nijer W Ulusal Parkı hariç) girebilmiştir. Ancak, 2005 ve sonrasındaki yıllarda gerek konumlanış biçimi gerekse paydaşlık ortalaması değişmiştir. 2005 öncesinde 2,04 olan

\footnotetext{
${ }^{14}$ Arnavutluk, Avusturya, Belçika, Bulgaristan, Hırvatistan, Almanya, İtalya, Romanya, Slovakya, Slovenya, İspanya ve Ukrayna'nın paydaş olduğu bu ormanlar toplam 12 devletin sınırları içinde yer almaktadır.

${ }^{15}$ Struve Jeodezik Yayı Belarus, Estonya, Finlandiya, Letonya, Litvanya, Norveç, Moldova, Rusya, İsveç ve Ukrayna olmak üzere 10 adet Avrupa ülkesinde yer almaktadır.
} 

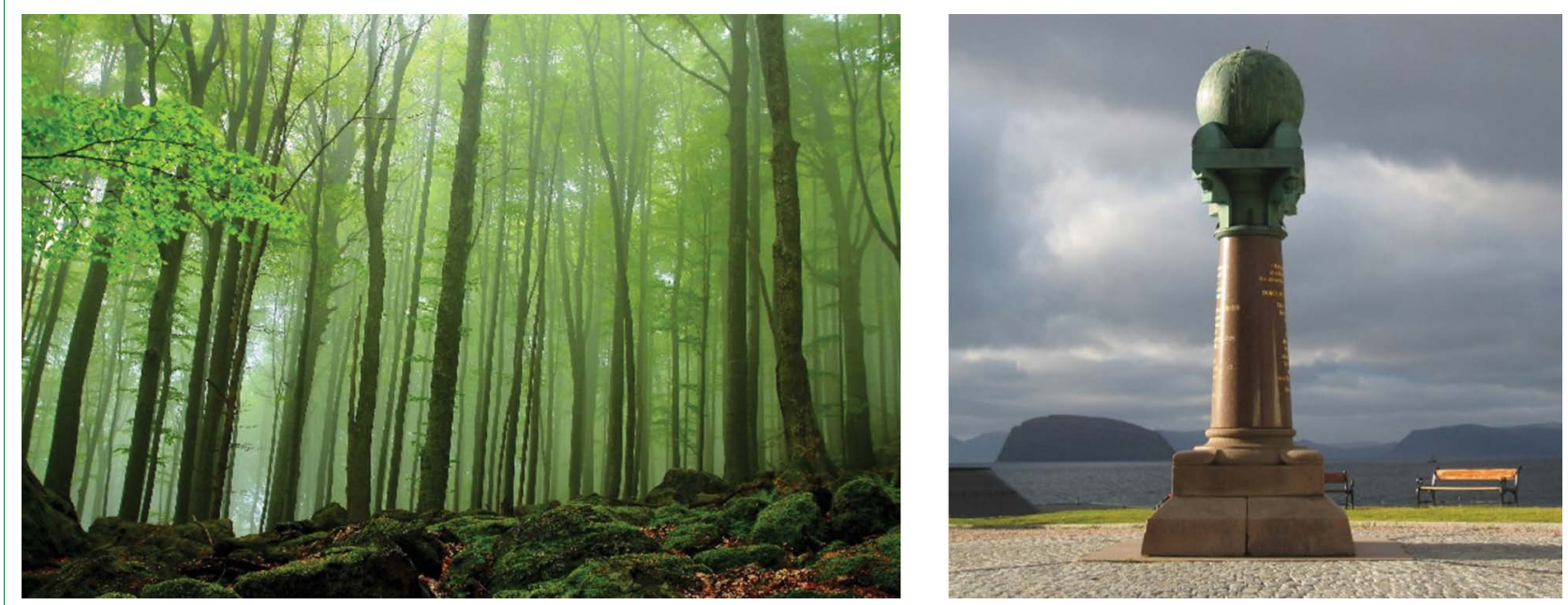

Şekil 4. Avrupa’nın kadim kayın ormanları (sol), Struve Jeodezik Yayı üzerinde bir nirengi noktası (sağ) (UNESCO, 20।9c).

Tablo 7. Sınırötesi mirasların konumlanışı ve paydaşlık durumu

\begin{tabular}{|c|c|c|c|c|}
\hline Periyot & Konumlanış & Sınırötesi miras sayısı & Oran (\%) & Miras başına paydaş ortalaması \\
\hline \multirow[t]{4}{*}{2005 öncesinde (1978-2004) } & 2 ülkede & 21 & 95,45 & \multirow{4}{*}{2,04} \\
\hline & 3 ülkede & 1 & 4,55 & \\
\hline & 3'den fazla ülkede & 0 & 0,00 & \\
\hline & Toplam & 22 & 100,00 & \\
\hline \multirow[t]{4}{*}{2005 ve sonrasında $(2005-2019)$} & 2 ülkede & 6 & 35,29 & \multirow{4}{*}{4,23} \\
\hline & 3 ülkede & 5 & 29,42 & \\
\hline & 3'den fazla ülkede & 6 & 35,29 & \\
\hline & Toplam & 17 & 100,00 & \\
\hline \multirow[t]{4}{*}{ 1978-2019 yılları arasında } & 2 ülkede & 27 & 69,24 & \multirow{4}{*}{3,00} \\
\hline & 3 ülkede & 6 & 15,38 & \\
\hline & 3'den fazla ülkede & 6 & 15,38 & \\
\hline & Toplam & 39 & 100,00 & \\
\hline
\end{tabular}

ortalama paydaş devlet sayısı, 2005 yılı sonrasında birbirine komşu olan ve olmayan devletlerin kurduğu ortaklıklarla listeye giren sınırötesi miraslar arasında 4,23 devlet, 1978-2019 yılları ortalamasında ise 3,00 devlet olarak gerçekleşmiştir. Bu bulgular, sınırötesi mirasların paydaşlık ortalamasının yükseldiğini, ayrıca paydaşlık ilişkilerinin yeni bir hal aldığını, bu çerçevede, coğrafi olarak birbirine komşu olmayan devletlerin de doğal ve kültürel miras alanlarını birlikte koruma çabası içine girdiğini göstermektedir. Bu bağlamda, 2016 yılında listeye giren şehirci-mimar Le Corbusier'in modern mimariye üstün katkı sağlayan çalışmaları, dikkati çeken özel bir yere sahiptir. 17 parçadan oluşan bu sınırötesi kültürel miras hem pek çok devlet tarafından paylaşılmaktadır, hem paydaş devletlerin hepsi birbirinin coğrafi olarak komşusu değildir ve hatta bu devletler farklı kıtalarda yer almaktadır. Ayrıca, bu miras DML'deki tek sınırötesi modern mimarlık mirasıdır (Şekil 5).

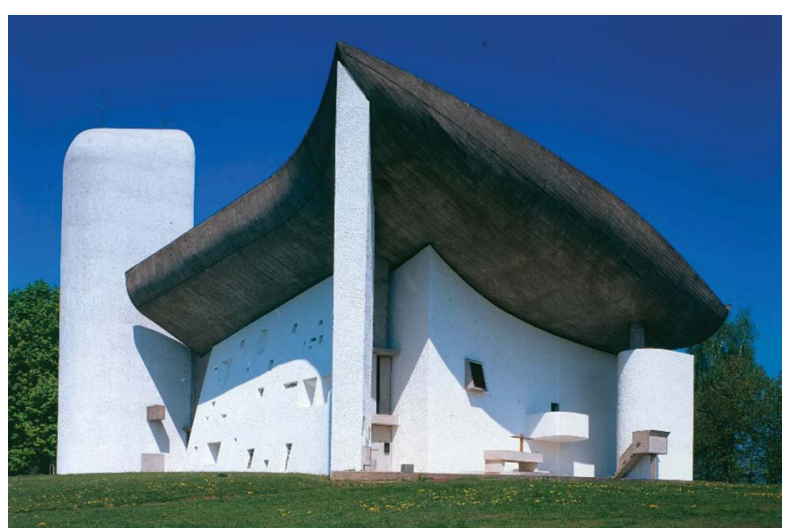

Şekil 5. Le Corbusier'in eserlerinden Notre-Dame du Haut Şapeli (UNESCO, 2019c). 
Tablo 8. Sınırötesi mirasların ve DM'nin bölgelere dağılımı

\begin{tabular}{|c|c|c|c|c|c|}
\hline \multicolumn{3}{|c|}{ Sınırötesi miraslar } & \multicolumn{3}{|c|}{ Bütün DM } \\
\hline Bölge & Sayı & Oran (\%) & Bölge & Sayı & Oran (\%) \\
\hline Afrika & 6 & 15,38 & Afrika & 96 & 8,56 \\
\hline Arap Ülkeleri & 0 & 0,00 & Arap Ülkeleri & 86 & 7,67 \\
\hline Asya-Pasifik & 4 & 10,27 & Asya-Pasifik & 268 & 23,91 \\
\hline Avrupa-Kuzey Amerika & 26 & 66,66 & Avrupa-Kuzey Amerika & 529 & 47,19 \\
\hline Latin Amerika & 3 & 7,69 & Latin Amerika & 142 & 12,67 \\
\hline Toplam & 39 & 100,00 & Toplam & $|12|$ & 100,00 \\
\hline
\end{tabular}

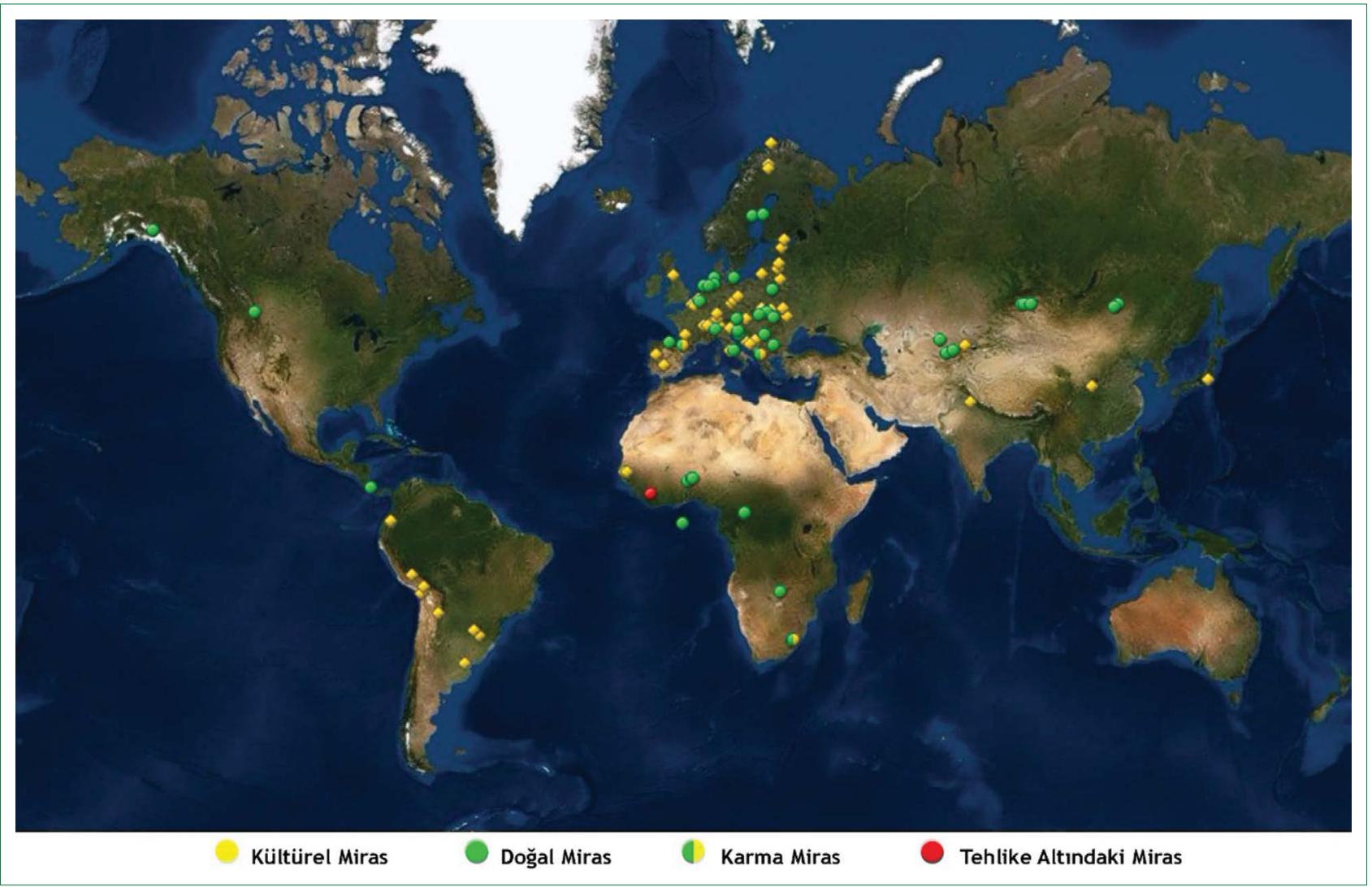

Şekil 6. Sınırötesi mirasların mekânsal dağıımı (UNESCO, 20।9a).

\subsection{Mekân Kesitinde Sınırötesi Miraslar: Bölgesel Dağııım, Türel Dağııı, Paydaşlık}

Sınırötesi miraslar ve DM genelinin bölgelere dağılımını gösteren Tablo 8'deki bulgular, sınırötesi mirasların üçte ikisinin Avrupa-Kuzey Amerika bölgesindeki ülkelerde, üçte birinin ise diğer bölgelerde bulunduğunu göstermektedir. DML'ye Ortadoğu'dan giren hiç sınırötesi miras bulunmamaktadır. Bu bulgular ışığında ve Şekil 6'daki haritadan da açıkça görüldüğü üzere, sınırötesi mirasların dünyadaki dağılımında Avrupa'nın çarpıcı bir oranla diğer bölgelerden önde olduğu anlaşılmaktadır. Öyle ki, Avrupa-Kuzey Amerika bölgesinin sınırötesi miraslar içindeki payı $(\% 66,66)$, DML'deki \%47, I9'luk genel payından da yüksektir. Öte yandan, Asya-Pasifik bölgesinin sınırötesi miraslar içindeki payı, DML'deki payının yarısından daha azdır. Dahası, kültürel miras bağlamında çok köklü ve zengin bir kıta olan Asya'dan bir sınırötesi miras, DML'ye ilk defa 2003 yılında girebilmiştir (bkz. Tablo 3).

Bu bulgular, sınırötesi mirasların bölgesel dağılımında önemli bir dengesizlik olduğunu, üstelik bu dengesizliğin DML genelinden de daha büyük olduğunu göstermektedir. Ayrıca, Tablo 3 incelendiğinde bölgesel dağılımdaki dengesizliğin süreç içinde önemli bir farklılık göstermediği anlaşılmaktadır. Sınırötesi 
Tablo 9. Sınırötesi mirasların ve DM'nin miras türlerine göre bölgelere dağıııı

\begin{tabular}{|c|c|c|c|c|c|c|c|}
\hline \multicolumn{4}{|c|}{ Sınırötesi miraslar } & \multicolumn{4}{|c|}{ DM } \\
\hline Miras türü & Bölge & Sayı & Oran (\%) & Miras türü & Bölge & Sayı & Oran (\%) \\
\hline \multirow[t]{6}{*}{ Sınırötesi kültürel miraslar } & Afrika & I & 5,00 & Kültürel miraslar & Afrika & 53 & 6,09 \\
\hline & Arap Ülkeleri & 0 & 0,00 & & Arap Ülkeleri & 78 & 8,98 \\
\hline & Asya-Pasifik & 2 & 10,00 & & Asya-Pasifik & 189 & 21,75 \\
\hline & Avrupa-K. Amerika & 16 & 80,00 & & Avrupa-K. Amerika & 453 & 52,13 \\
\hline & Latin Amerika & 1 & 5,00 & & Latin Amerika & 96 & 11,05 \\
\hline & Toplam & 20 & 100,00 & & Toplam & 869 & 100,00 \\
\hline \multirow[t]{6}{*}{ Sınırötesi doğal miraslar } & Afrika & 4 & 25,00 & Doğal miraslar & Afrika & 38 & 17,84 \\
\hline & Arap Ülkeleri & 0 & 0,00 & & Arap Ülkeleri & 5 & 2,35 \\
\hline & Asya-Pasifik & I & 6,25 & & Asya-Pasifik & 67 & 31,45 \\
\hline & Avrupa-K. Amerika & 8 & 50,00 & & Avrupa-K. Amerika & 65 & 30,52 \\
\hline & Latin Amerika & 3 & 18,75 & & Latin Amerika & 38 & 17,84 \\
\hline & Toplam & 16 & 100,00 & & Toplam & 213 & 100,00 \\
\hline \multirow[t]{6}{*}{ Sınırötesi karma miraslar } & Afrika & I & 33,33 & Karma miraslar & Afrika & 5 & 12,82 \\
\hline & Arap Ülkeleri & 0 & 0,00 & & Arap Ülkeleri & 3 & 7,69 \\
\hline & Asya-Pasifik & 0 & 0,00 & & Asya-Pasifik & 12 & 30,77 \\
\hline & Avrupa-K. Amerika & 2 & 66,67 & & Avrupa-K. Amerika & II & 28,21 \\
\hline & Latin Amerika & 0 & 0,00 & & Latin Amerika & 8 & 20,51 \\
\hline & Toplam & 3 & 100,00 & & Toplam & 39 & 100,00 \\
\hline
\end{tabular}

mirasların DML'ye girmeye başladığı ilk yıllardan günümüze değin kesintisiz bir şekilde, Avrupa sınırötesi miras listesinde majör bir paya, diğer bölgeler ise minör paylara sahip olmuştur. Bu durum 1994'te alınan dengeli ve temsili bir liste kararına hiç uygun düşmemektedir.

Sınırötesi mirasların bölgesel dağııımı Tablo 9 üzerinden incelendiğinde, mekânsal farklılıkların yalnızca miras sayısı bakımından değil, aynı zaman da türel olarak da var olduğu anlaşılmaktadır. Tablo 9'da sunulan bulgulara göre, sınırötesi kültürel mirasların neredeyse tamamı denebilecek kadar büyük bir bölümü $\left(\% 80^{\prime} i\right)$ tek bir bölgede yer almaktadır. Bu bulgu, DML'deki mirasların türlerine göre bölgesel dağıımında görülen dengesizliğin, sınırötesi miraslar arasında çok daha çarpıcı bir boyutta olduğunu göstermektedir. Bu çerçevede, Avrupa'nın sahip olduğu kültürel miras varlığının miktarı noktasında, hem genel olarak DM içinde diğer bölgelere kıyasla önde hem de kültürel miraslarını korumak için uluslararası işbirlikleri kurma noktasında oldukça ileri bir seviyede olduğunu söylemek mümkündür. Ha keza, doğal ve karma nitelikteki mirasların korunması noktasında da başarıııdır. Zira bu bölge doğal ve karma nitelikteki miras sayısı bakımından DML'de ikinci sırada yer almasına rağmen, sını̈ötesi miras listesinde birinci sırada bulunmaktadır. Sonuç olarak, bütün sınırötesi miras türlerinde Avrupa-Kuzey Amerika bölgesi hem diğer bölgelerden önde, hem de bu bölgenin sınırötesi miras listesindeki toplam payı DML'deki genel payından daha yüksektir.

Öte yandan, sını̈ötesi miraslar-paydaşlık ilişkisinde de mekânsal farklıııklar bulunmaktadır. Tablo I0'daki bulgular, miras başına ortalama paydaş devlet sayısının en yüksek Latin Amerika ve Karayipler'de olduğunu göstermektedir. ${ }^{16}$ Bununla birlikte, sını̈ötesi miras sahibi devlet sayısının en yüksek olduğu bölge Avrupa-Kuzey Amerika'dır. Ayrıca, Tablo 3 incelendiğinde, paydaş sayısı üçten fazla olan altı adet mirasın beşinin ve ayrıca on ve üzeri paydaş devleti olan iki adet sınırötesi mirasın ikisinin de Avrupa kıtasında yer aldığı görülmektedir. ${ }^{17}$ Ayrıca, Avrupa'daki sınırötesi mirası olan devletlerin birçoğu birden çok sınırötesi mirasa sahiptir. Almanya 7 adet varlık ile listede en çok sınırötesi mirası olan ülkedir. Onu 6 sınırötesi miras ile İtalya ve dörder sınırötesi miras ile Fransa, İspanya, İsviçre ve Rusya izlemektedir (Tablo 3).

16 DML'deki 3 varlık DMM'nin bölge tanımlamasına göre birden çok bölgede yer almaktadır. DMM kategorik değerlendirmelerinde, 3 kıtada bulunan Le Corbusier'in Eserlerini (Avrupa-Kuzey Amerika, Asya-Pasifik, Latin Amerika) Avrupa-Kuzey Amerika bölgesinde; Dauria peyzajları ve Uvs Nuur havzasını (Asya-Pasifik, Avrupa-Kuzey Amerika) Asya-Pasifik'de gruplandırmaktadır.

${ }^{17}$ Bu miraslar, Avrupa'nın kadim kayın ormanları, Struve Jeodezik Yayı, Alpler'deki tarihöncesi göl-üstü kazıklı evler, Stećci ortaçağ mezartaşları-mezarlıkları ve modern mimariye üstün katkı sağlayan Le Corbusier'in çalışmalarıdır. 
Tablo 10. Bölgelere göre paydaşık ilişkileri

\begin{tabular}{lcccc}
\hline Bölge & $\begin{array}{c}\text { Sını̈ötesi } \\
\text { miras sayısı }\end{array}$ & $\begin{array}{c}\text { Sınırötesi miras sahibi } \\
\text { devlet sayısı }\end{array}$ & $\begin{array}{c}\text { Sınırötesi mirasların } \\
\text { paydaş sayısı }\end{array}$ & $\begin{array}{c}\text { Miras başına ortalama } \\
\text { paydaş devlet sayısı }\end{array}$ \\
\hline Avrupa \& Kuzey Amerika & $\mathbf{2 6}$ & $\mathbf{3 7}$ & $\mathbf{8 3}$ & 3,19 \\
Afrika & 6 & 14 & 14 & 2,33 \\
Asya-Pasifik & 4 & 7 & 13 & 3,25 \\
Latin Amerika & 3 & 9 & 10 & 3,33 \\
Toplam & 39 & 67 & 120 & 3,07 \\
\hline
\end{tabular}

Tablo I I. Sahip oldukları sını̈r̈tesi miras sayısına göre devletlerin bölgelere dağılımı

\begin{tabular}{|c|c|c|c|}
\hline & Bölge & Sayı & Oran (\%) \\
\hline \multirow[t]{4}{*}{ Birden çok sınırötesi miras varlığı bulunan devletler } & Avrupa-Kuzey Amerika & 21 & 80,77 \\
\hline & Asya-Pasifik & 4 & 15,38 \\
\hline & Latin Amerika & 1 & 3,85 \\
\hline & Toplam & 26 & 100,00 \\
\hline \multirow[t]{5}{*}{ Bir adet sınırötesi mirası olan devletler } & Avrupa-Kuzey Amerika & 15 & 36,58 \\
\hline & Afrika & 14 & 34,15 \\
\hline & Latin Amerika & 8 & $|9,5|$ \\
\hline & Asya-Pasifik & 4 & 9,76 \\
\hline & Toplam & 41 & 100,00 \\
\hline
\end{tabular}

Tablo II'deki bulgular incelendiğinde, birden çok sınırötesi mirası olan ülkelerin \%80,77'sinin Avrupa-Kuzey Amerika bölgesinde yer aldığı görülmektedir. Afrika'da birden çok sınırötesi mirasa sahip devlet yoktur. Sınırötesi miras varlığı bulunan ülkelerin \%6I, I9'u tek bir mirasa sahiptir ve bunların \%63,42'si Avrupa dışındaki dünyanın geri kalanındadır. Sınırötesi mirası olan devletler, partner sayılarına göre sıralandıklarında ise Almanya ve Ukrayna 2 I adet partner ile birinci sırada yer almaktadır. Onları sırasıyla Belçika, İtalya, Avusturya, Hırvatistan, İspanya, Slovenya, Slovakya ve Arjantin izlemektedir (bkz. Tablo 3). Dikkat edilirse, bu sıralamada Arjantin hariç, diğer bütün ülkeler birden çok sınırötesi mirasa sahip Avrupa ülkeleridir. Dolayısıyla, Avrupa ülkelerinin kültürel ve doğal miraslarını DML'ye ekletmekte başarılı oldukları kadar, çoklu ortaklıklar kurmak bakımından da daha başarılı oldukları anlaşılmaktadır.

\section{Sonuç ve Öneriler}

\section{I. Sonuç}

Bu araştırmada DML'de birden çok devletin sınırları içinde yer alan sınırötesi mirasların zaman ve mekân kesitindeki gelişimi DM geneli ile karşılaştırmalı olarak incelenmiştir. Yapılan analizler, sınırötesi mirasların tek yapı ölçeğinden yerleşme boyutuna, büyük sanat eserlerinden kültürel anlam kazanmış basit eserlere kadar uzanan ve doğal alanları da içeren geniş bir miras çeşitliliği sunduğunu; risk altındaki mirasların oransal olarak sınırötesi miraslar arasında DML geneline kıyasla daha az olduğunu dolayısıyla mirasların uluslararası ortaklıklarla daha iyi korunabildiğini; ayrıca, sınırötesi miras listesinin miras sayısı, türü ve paydaşlık ilişkileri bağlamında belirgin zamansal ve mekânsal farklılıklar içerdiğini ve bu durumun DML geneli ile kısmen örtüştüğünü kısmen de ayrıştığını ortaya koymuştur.

Araştırma bulgularının bir özetini sunan Tablo I2'de görüldüğü gibi, zaman kesitinde, sınırötesi miras listesinin 3 önemli dönüm noktası bulunmaktadır. Bu bağlamda, 1995 senesi miras sayısının düzenli ve ivmelenerek artmaya başladığı yıl, 2000 senesi türel dağılım oranlarının kültürel miraslar lehine değişmeye başladığı yıl, 2005 senesi ise konumlanış ve paydaşIık ilişkilerinin dönüşmeye başladı̆̆ı, bu çerçevede, ülkelerin gerek coğrafi olarak komşusu olan devletlerle gerekse komşusu olmayan devletlerle çoklu ortaklıklar kurmaya başladığı, böylece, paydaşlık ortalamasının yükseldiği yıldır. Fakat bu tarihler DML geneli için bir dönüm noktası değildir. Zira DML kuruluşundan bu yana -1994'te alınan güvenilir, temsili ve dengeli bir DML kararına rağmen- dönemsel farklılık göstermeyen ancak türel dağıım bağlamında dengesiz bir genişleme içindedir ve ne yazık ki, DML genelinde türel dağılım dengesinin kısa bir zaman diliminde gerçekleştirilebilmesi mümkün görünmemektedir. 
Tablo I2. Zaman ve mekân kesitinde sınırötesi miraslar ve DM, özet bulgular matrisi

\begin{tabular}{|c|c|c|c|}
\hline & Miras & $\ddot{u}$ & (1) \\
\hline & $\begin{array}{l}\text { DML genelinde yıllık ortalama büyümede } \\
\text { dönemsel bir farklılık yoktur, fakat } \\
\text { sınırötesi miras listesinde vardır. Bu } \\
\text { bağlamda, sınırötesi miras listesinde } \\
\text { I995 öncesinde yıllık büyüme: 0,53 miras } \\
\text { I995 sonrasında yıllık büyüme: I,20 miras } \\
\text { I978-20।9 yılları bütününde yıllık büyüme: } \\
0,95 \text { miras } \\
1995 \text { öncesinde DML'deki oranı: \%2,05 } \\
\text { I995 sonrasında DML'deki oranı: \%4,39 } \\
\text { I978-20।9 yılları bütününde DML'deki } \\
\text { oranı: \%3,48 } \\
\text { Miras güvenliği sını̈ötesi miras listesinde } \\
\text { daha iyidir. Zira risk altında yalnızca bir } \\
\text { sınırötesi miras vardır (\%2,5). DML'de risk } \\
\text { altındaki mirasların toplam oranı: \%4,73 }\end{array}$ & $\begin{array}{l}\text { DML genelinde mirasların türel dağılımı } \\
\text { dengeli değildir. Kültürel miraslar }(\% 77,52) \\
\text { lehine olan bir dengesizlik vardır. Bu } \\
\text { hususta dönemsel bir farklılık yoktur. } \\
\text { Sını̈ötesi mirasların türel dağılımı } \\
\text { hâlihazırda dengelidir. Ancak, dağılımda } \\
\text { dönemsel farklılıklar vardır. } \\
2000 \text { öncesinde: doğal miraslar lehine } \\
\text { dengesizlik (\%53,34) } \\
2000 \text { sonrasında: kültürel miraslar lehine } \\
\text { dengesizlik (\%62,50) } \\
\text { I978-20।9 yılları bütününde: görece } \\
\text { dengede (\%5।,28 kültürel, \%4I,03 doğal) }\end{array}$ & $\begin{array}{l}\text { Sınırötesi miraslar-paydaşlık ilişkisinde } \\
\text { dönemsel farklılık vardır. } \\
2005 \text { öncesinde paydaş ortalaması: } 2,04 \\
\text { devlet } \\
2005 \text { sonrasında paydaş ortalaması: } 4,23 \\
\text { devlet } \\
\text { 1978-2019 yılları bütününde paydaş } \\
\text { ortalaması: } 3 \text { devlet } \\
2005 \text { öncesinde konumlanış: mutlak komşu } \\
\text { devletlerde } \\
2005 \text { sonrasında konumlanış: mutlak } \\
\text { komşu + komşu olmayan devletlerde }\end{array}$ \\
\hline & $\begin{array}{l}\text { Hem DM genelinin hem de sınırötesi } \\
\text { mirasların bölgelere dağılımında nicel } \\
\text { dengesizlik vardır. Ancak sınırötesi miras } \\
\text { listesi bölgesel dağıım açısından DML'ye } \\
\text { göre daha dengesizdir. Ayrıca bu listede } \\
\text { Ortadoğu'dan miras yoktur. } \\
\text { Mirasların bölgesel dağıııııdaki } \\
\text { dengesizlikte belirleyici bölge Avrupa- } \\
\text { Kuzey Amerika'dır. Bu bölgenin } \\
\text { DML'deki miras oranı: \%47, I4 } \\
\text { Sınırötesi miras listesindeki oranı: \%66,66 } \\
\text { DML'de risk altındaki mirasların \%69,8I’i } \\
\text { Afrika ve Arap ülkelerindedir. } \\
\text { Risk altındaki tek sını̈ötesi miras } \\
\text { Afrika'dadır. }\end{array}$ & $\begin{array}{l}\text { Hem DM genelinin hem de sınırötesi } \\
\text { mirasların bölgelere dağılımında türel } \\
\text { dengesizlik vardır. } \\
\text { Bu dengesizlikte belirleyici tür kültürel } \\
\text { miraslar olup, belirleyici bölge Avrupa- } \\
\text { Kuzey Amerika'dır. Bu bölgenin } \\
\text { DML'deki kültürel miras oranı: \%52, I3 } \\
\text { Sınırötesi miras listesindeki kültürel miras } \\
\text { oranı: \%80 }\end{array}$ & $\begin{array}{l}\text { Sınırötesi miraslar-paydaşlık ilişkisinde } \\
\text { mekânsal farklılık vardır. } \\
\text { Latin Amerika bölgesinde ortalama paydaş } \\
\text { devlet sayısı en yüksek olmakla birlikte, en } \\
\text { çok paydaşı olan miraslar ve en çok miras } \\
\text { ortağı olan devletler Avrupa'dadır. } \\
\text { Türkiye'nin paydaş olduğu bir sınırötesi } \\
\text { miras varlığı yoktur. }\end{array}$ \\
\hline
\end{tabular}

Özetle, 2019 yılı itibariyle, sınırötesi mirasların türel dağııım bağlamında DM geneline kıyasla anlamlı bir dengeye ulaştığı, ilerleyen yıllarda da miras çeşitliliği gözetilerek listeleme yapıldığı takdirde türel dağııım dengesinin geliştirilerek korunabileceği düşünülebilir. Öte yandan, dengeli bir DML hedefinin gerçekleştirilebilmesi için doğal miraslar lehine gelişecek bir yönelimin olması gerekmektedir ya da DML'nin temsili ve dengeli bir liste olması yönündeki tartışmalar daha uzun bir süre devam edecektir.

Mekân kesitinde ise hem sınırötesi mirasların hem de DM genelinin bölgesel dağılımında çok büyük dengesizlikler söz- konusudur. Burada belirleyici bölge Avrupa'dır. Bu bölge DM'nin yaklaşık yarııına, sınırötesi mirasların yarıdan fazlasına, sınırötesi kültürel mirasların ise neredeyse tamamına sahiptir. Ayrıca sınırötesi miras sahibi devletlerin yarıdan fazlası Avrupa'dadır. Bu durum, Avrupa ülkelerindeki kültürel ve doğal çevrenin korunması hususundaki yüksek bilinç düzeyinin, köklü planlama geleneğinin ve kültürünün, uluslararası bölgesel işbirlikleri kurmadaki zengin tecrübenin ve kolektif düşünme biçiminin bir sonucu olarak değerlendirilebilir. Öte yandan, Türkiye'nin önemli bir potansiyeli olmakla birlikte henüz DML'de herhangi bir sınırötesi miras varlığı yoktur. Ayrıca, DML'de Ortadoğu'dan hiçbir sınırötesi miras bulunmamakta- 
dır. Bu bölgede kültürel ve doğal mirasın korunmasına yönelik sınırötesi işbirliklerinin kurulamamasının pek çok nedeni olabilir, ancak en önemli nedenlerden birinin, bölgede on yıllardır hüküm süren huzursuzluk, çatışma ve savaş ortamının olması düşünülebilir. Özetle, 2019 yılı itibariyle, sınırötesi miraslar bölgesel dağılım bağlamında DM geneline kıyasla daha dengesizdir. Sınırötesi kültürel mirasların tamamına yakın bir bölümünün bir bölgede toplanması güvenilir, temsili ve dengeli bir liste hedefinden çok uzak bir durumu göstermektedir. İlerleyen yıllarda Avrupa dışındaki bölgelerden seçilecek sınırötesi kültürel miraslar, sınırötesi mirasların bölgesel dağılımında anlamlı bir denge kurulmasına katkı koyacaktır.

\subsection{Araştırma ve Politika Önerileri}

Uluslarası koruma alan yazınında sınırötesi koruma alanlarına ilişkin pek çok çalışma bulunmakla birlikte, DML'deki sınırötesi miraslar hakkında yapılmış araştırmalar görece sınırlıdır. Ulusal alan yazınımız ise tarihi ve doğal çevre koruma konularında önemli bir birikim ortaya koymakla birlikte, sınırötesi koruma alanları ve sınırötesi miraslar konusunda oldukça fakir bir durumdadır. Türkiye'nin henüz DML'de yer alan bir sınırötesi mirasının bulunmamasının sınırötesi koruma alan yazınımızın gelişmemiş olmasında etken olmuş olabileceği düşünülebilir. Ancak, DM'nin uluslararası işbirliğiyle korunmasının faydaları, bu çerçevede sınırötesi miras sahibi ülkelerin gerek varlıklarını koruma ve geliştirme yönündeki kazanımları gerekse sosyal-ekonomik vd alanlardaki kazanımları dikkate alındığında, yanı sıra Türkiye'nin sınırötesi miras potansiyeli gözönünde bulundurulduğunda, bu konudaki ilgi eksikliği ve alan yazınımızın gelişmemişliği kabul edilemez. Bu bağlamda, sınırötesi koruma alanları ve sınırötesi miraslar üzerine pek çok araştırma yapılmalı, konuyu farklı boyutlarıyla ele alan bilimsel çalışmalar yürütülmeli, lisansüstü öğrencilerinin yüksek lisans ve doktora tezlerinde sınırötesi mirasları çalışmaları teşvik edilmeli, desteklenmelidir.

Sonraki araştırmaların, sınırötesi miras koruma tecrübesi olan ülkelerin - özellikle de başta 21 ortaklı ve 7 miraslı Almanya ve diğer çok ortaklı ve çok miraslı Avrupa ülkeleri olmak üzere - sınırötesi mirasların planlanması, korunması ve yönetimine ilişkin geliştirdikleri politika, düzenleme ve uygulamalara odaklanması öğretici, yol gösterici ve ışık tutucu olacaktır. Bu bağlamda, örneğin Le Corbuser'in eserlerinin listelenmesi için kurulan işbirlikleri ilham verici bir rol model olarak detaylı bir şekilde incelenmelidir.

Araştırılması gereken bir diğer önemli husus, Türkiye'nin sınırötesi miras potansiyelidir. Zira Türkiye Cumhuriyeti'nin üzerinde kurulduğu kadim coğrafya, gerek yakın çevresi gerekse uzak çevresi ile birlikte düşünüldüğünde, Türkiye'nin DML'de değerlendirilebilecek sınırötesi miras potansiyeli üzerinde önemle çalışılması gerekliliği ortaya çıkmaktadır. Bu çerçeve- de, Türkiye'nin coğrafi komşusu olan/olmayan devletlerle ortaklık gösteren doğal, kültürel veya karma nitelikli sınırötesi miras potansiyeli incelenmeli ve sınırötesi işbirlikleri kurulmalıdır. Bu bağlamda, öncelikle, Türkiye Cumhuriyeti ve başka devletlerin sınırları içinde yer alan Mimar Sinan eserlerinin mevcut durumları incelenerek, bunların içinde üstün evrensel değer taşıyanların sınırötesi kültürel miras varlığı olarak DML'ye eklenmesi yönünde çalışmalar gerçekleştirilmelidir. Zira güncel eğilimlerin kültürel mirasların listelenmesinden yana olduğu bir dönemde, hâlihazırda Türkiye ve Bosna-Hersek'deki bazı yapıları DML'ye kültürel miras varlığı olarak girmiş olan Sinan'ın eserleri ile başlamak, Sinan'ın çatışma bölgelerinde ve diğer bölgelerdeki eserleri yıkılıp, yok olmadan ya da bakımsızlık/yanlış ve kötü restorasyon çalışmalarıyla bozulmadan; bu yapıların bütüncül bir yaklaşımla ve uluslararası işbirliğiyle korunmasını sağlayabilir. Bu çerçevede, öncelikle, Kültür Bakanlığının girişimiyle ve üniversitelerin rehberliğinde, Mimarlar Odası, Şehir Plancıları Odası, ÇEKÜL vd. sivil toplum kuruluşlarının da desteği alınarak, Bosna-Hersek'teki ve Sinan eserlerine ev sahipliği yapan diğer ülkelerdeki kamu kurumları ve sivil toplum kuruluşlarıyla işbirliği içinde Mimar Sinan'ın Türkiye sınırları dışında kalan eserlerinin mevcut durumlarının tespiti ve değerlendirmesi yapılmalı, ardından, UNESCO'ya gerekli başvurular yapılmalı ve ısrarlı bir şekilde lobi faaliyetleri yürütülmelidir.

Sinan'ın eserlerinin yanı sıra, Türkiye'nin bütün sınırötesi miras potansiyeli holistik bir ele alışla incelenmelidir. Zira bu potansiyelin DML'de değerlendirilmesi, sınırlarımız içinde ve dışında korunmaya değer varlıkların pek çok devletin işbirliği ile daha iyi korunmasında, yanı sıra, Türkiye'nin uzak ve yakın komşuları ile sosyal, kültürel ve ekonomik ilişkilerinin geliştirilmesinde, turizm faaliyetlerindeki artışla sürdürülebilir kalkınmada etkili olacaktır. Ayrıca, bu çabaların, dört tarafı ateş çemberi ile sarılmış olan Türkiye'nin komşuları ile ve komşularının da birbirleri ile barışına katkı koyması beklenmelidir. Zira buna, günümüzde, herkesin her zamankinden daha fazla ihtiyacı vardır. 


\section{KAYNAKLAR}

Ahunbay, Z. (2011). Tarihi Çevre Koruma ve Restorasyon, YEM Yayın - 28, İstanbul.

Akurgal, E. (2015). Anadolu Kültür Tarihi. Ankara: Phoenix Yayınevi.

Albrecht, M. (2010). Transboundary Governance of the Curonian Spit World Heritage Site. Journal of Environmental Planning and Management, 53 (6), 725-742.

Ali, S. H. (2010). Transboundary Conservation and Peace-building: Lessons from Forest Projects. Yokohama, Japan: International Tropical Timber Organization (ITTO) and the United Nations University Institute of Advanced Studies.

Alsdirawi, F., Faraj, M. (2004). Establishing a Transboundary Peace Park in the Demilitarized Zone (DMZ) on the Kuwaiti/Iraqi Borders. Parks, 14 (1), 48-55.

Altınöz, G. (2012a). Kültürel Miras ve Koruma Anlayışının Tarihsel Gelişimi. M. Ersoy (Ed.), Kentsel Planlama Ansiklopedik Sözlük içinde (s. 299 303). İstanbul: Ninova.

Altınöz, G. (2012b). Kültürel Mirasın Korunmasına İlişkin Uluslararası Belgeler ve Sözleşmeler. M. Ersoy (Ed.), Kentsel Planlama Ansiklopedik Sözlük içinde (s.305-310). İstanbul, Ninova.

Armaitienè, A. (2007). Integrated Shoreline Management and Tourism Development on the Cross-border World Heritage Site: A Case Study from the Curonian Spit (Lithuania/Russia). Journal of Coastal Conservation, $11(1), 13-22$.

Aslanapa, O. (1988). Mimar Sinanin Hayatı ve Eserleri. Ankara: Türk Kültürünü Araștırma Enstitüsü.

Batur, A., Batur, S. (1967). Sinan'a Ait Yap1ların Listesi. Mimarlık, 49, 35-39.

Biodiversity Support Program (2001a). Beyond Boundaries: Transboundary Natural Resource Management in West Africa. Washington: Biodiversity Support Program.

Biodiversity Support Program (2001b). Beyond Boundaries: Transboundary Natural Resource Management in Eastern Africa. Washington: Biodiversity Support Program.

Braack, L., Petermann, T., Sandwith, T.S. (2003). Transboundary Protected Areas in Southern and Eastern Africa: A Summary Synthesis of the Findings of Five Regional Workshops Held During 2002 and 2003. Unpublished Report by Internationale Weiterblidung und Entwicklung (InWEnt), Zschortau.

Braack, L., Sandwith, T., Peddle, D., Petermann, T. (2006). Security Considerations in the Planning and Management of Transboundary Conservation Areas. Gland, Switzerland and Cambridge, UK: IUCN.

Bushell, R., Eagles P. F. J. (2007). Tourism and Protected Areas: Benefits beyond Boundaries. The Vth IUCN World Parks Congress. Gateshead, UK: CABI.

Carroll, J.E. (1979). International Peace Parks: A Concept and a Proposal. J.G. Nelson, R.D. Needham, S.H. Nelson, R.C. Scace (Ed.), The Canadian National Parks: Today and Tomorrow (Conference No. 2) içinde (s.725-730), Waterloo, Canada: Heritage Resources Centre, University of Waterloo.

Chifamba, E. (2012). Transboundary Natural Resource Management and Distribution of Rights and Benefits to Local Communities on the Zimbabwe - South African Border. International Journal of Politics and Good Governance, 3(4), 1-27.

Church, A.L. (2012). Scale \& Context: An Evaluation of Regional and Transboundary Heritage Conservation Models. (Unpublished Masters Thesis), University of Pennsylvania, Philadelphia.

ÇEKÜL (2019). Sinana Sayg1 Projesi. (http://www.sinanasaygi.org/), Son Erişim Tarihi: 14.11 .2019

Danby, R.K., Slocombe, D.S. (2005). Regional Ecology, Ecosystem Geography and Transboundary Protected Areas in the St. Elias Mountain Parks. Ecological Applications, 15(2), 405-422.
Danby, R.K., Slocombe, D.S. (2002). Protected Areas and Intergovernmental Cooperation in the St. Elias Region. Natural Resources Journal, 42, 247-282.

Danby, R.K. (1997). International Transborder Protected Areas: Experience, Benefits, and Opportunities. Environments, 25(1), 1-14.

Demireş Özkul, B., Pouya, S. (2017). Barış Parkları; Sınırötesi Korunmuş Alanlar. Plant, Peyzaj ve Süs Bitkiciliği Dergisi, [http://www.plantdergisi.com/yrd-doc-dr-basak-demires-ozkul/baris-parklari-sinir-otesi-korunmus-alanlar.html] Son Erişim (14.11.2019).

Dinçer, İ. (2012). Dünya Miras Listesi. M. Ersoy (Ed.), Kentsel Planlama Ansiklopedik Sözlük içinde (s.95-97). İstanbul: Ninova.

Dinçer, İ., Enlil, Z., Evren, Y., Kozaman Som, S. (2011). İstanbul'un Tarihi ve Doğal Miras Değerleri: Potansiyeller, Riskler ve Koruma Sorunları. İstanbul Bilgi Üniversitesi Yayınları, İstanbul.

Erzen, J. N. (2005). Mimar Sinan, Estetik Bir Analiz. İstanbul: Şevki Vanlı Mimarlık Vakfı Yayınları.

Güçhan, N.Ş., Kurul, E. (2009). A History of the Development of Conservation Measures in Turkey: From the Mid 19th Century until 2004. METU JFA, 26(2), 19-44.

Günay, R. (2014). Mimar Sinan. İstanbul: YEM Yayınları.

Gür, S. (2010). Anadolu Uygarlıkları ve Antik Şehirler. İstanbul: Alfa Yayınlari.

Haapala, H. (2003). Finnish-Russian Nature Conservation Co-operation. Helsinki: Finnish Ministry of the Environment.

Hamilton, L. S. (1996). Transbourder Protected Area Co-operation. J.Cerovsky (Ed.) Biodiversity Conservation in Transboundary Protected Areas in Europe içinde (s.9-18), Prague, Czech Republic: Ecopoint.

IUCN/WCPA (1998). Transboundary Protected Areas as a Vehicle for International Co-operation. Proceedings, Parks for Peace Conference, September 16-18, 1997. Somerset West, South Africa.

Kuban, D. (2012). Türkiyéde Kentsel Koruma, Kent Tarihleri ve Koruma Yöntemleri. İstanbul: Tarih Vakfı Yurt Yayınları.

McCallum, J., Vasilijević, M., Cuthill, I. (2014). Assessing the Ecological Benefits of Transboundary Protected Areas (TBPA): A Questionnaire Survey in the Americas and the Caribbean. Journal of Environmental Management 149: 245-252.

Mcneely, J.A. (Ed.) (1995). Expanding Partnerships in Conservation. Washington D.C.: Island.

Özdemir, M.Z. (2005). Türkiyéde Kültürel Mirasın Korunmasına Kısa Bir Bakıș. Planlama, 31, 20-25.

Philips, D., Daoudy, M., McCaffrey, S., Jendal, J., Turton, A. (2006). Transboundary Water Cooperation as a Tool for Conflict Prevention and for Broader Benefit-sharing. Sweden: Ministry for Foreign Affairs.

Pouya, S., Demireş Özkul, B., Demirel, Ö. (2017). "Planning for Peace Through Transboundary Conserved Areas", 2. International Congress on Engineering Architecture and Design, 12-13 Mayıs 2017, Kocaeli, 531-532.

Rüster, B., Simma, B. (Ed). (1975). International Protection of the Environment: Treaties and Related Documents. First Series. Dobbs Ferry, NY: Oceana Publications.

Saatçi, S. (2014). Bir Osmanlı Mucizesi, Mimar Sinan. İstanbul: Ötüken Neşriyat.

Sandwith, T., Shine, C., Hamilton, L., Sheppard, D. (2001). Transboundary Protected Areas for Peace and Co-operation. Gland, Switzerland \& Cambridge, UK: IUCN - The World Conservation Union.

Stolton, S., Dudley, N. (Ed.) (1999). Partnerships for Protection, New Strategies for Planning and Management of Protected Areas. Gland, Switzerland: IUCN and WWF-International.

Svels, K., Sande, A. (2016). Solving Landscape-related Conflicts through Transnational Learning? The Case of Transboundary Nordic World Heritage Sites. Landscape Research, 41(5), 524-537.

Tankut, G. (2005). Doğal ve Tarihi Çevrenin Korunması: Sorunlar ve Olası Çözümler. Planlama, 31, 9-12. 
Tekeli, İ. (2011). Kültür Politikaları ve İnsan Hakları Bağlamında Doğal ve Tarihi Çevreyi Korumak. İstanbul: Tarih Vakfı Yurt Yayınları.

Thorsell, J. W., Harrison, J. (1990). Parks that Promote Peace. A Global Inventory of Transfrontier Nature Reserves. Thorsell, J. W. (Ed.) Parks on the Borderline, Experience in Transfrontier Conservation içinde. Gland, Switzerland and Cambridge, UK: IUCN.

Ulusan, E., Yıldırım, E. (2016). Temsili, Dengeli ve Güvenilir Bir Liste İçin: Türkiyénin Dünya Mirası Adaylıklarının Gözden Geçirilmesi. İdeal Kent - Kent Araștırmaları Dergisi, 19, 444-473.

UNESCO (2019a). World Heritage List. World Heritage Center [http:// whc.unesco.org/en/list/] Son Erişim Tarihi (14.11.2019).

UNESCO (2019b). Official World Heritage List Statistics. World Heritage Center [http://whc.unesco.org/en/list/stat] Son Erişim Tarihi (14.11.2019).

UNESCO (2019c). Transboundary Heritages. World Heritage Center [http://whc.unesco.org/en/list/?\&transboundary=1] Son Erişim (14.11.2019).

UNESCO (2019d). Transboundary Cooperation for Conservation of World Heritage - A Global View. UNESCO World Heritage Centre, Expert Meeting 3-4 June 2019 Maun, Botswana.

UNESCO (2017). Perspectives of Transboundary Cooperation in World Heritage, Sharing Experiences in and around Germany. Conference Report, 12-13 December 2016. Bonn, Germany: German Commission for UNESCO.

UNESCO (1972). Convention Concerning the Protection of the World Cultural and Natural Heritage. UNESCO, Paris [http://whc.unesco.org/ archive/convention-en.pdf] Son Erişim Tarihi (14.11.2019).

Vasilijević, M. (2012). Challenges and Opportunities of Transboundary Conservation in the Dinaric Arc. Erg, B., Vasilijević, M., McKinney, M. (Ed.). Initiating Effective Transboundary Conservation: A Practitioner's Guideline Based on the Experience from the Dinaric Arc içinde. Gland, Switzerland and Belgrade, Serbia: IUCN Programme Office for SouthEastern Europe.

Vasilijević, M., Pezold, T. (Ed.). (2011). Crossing Borders for Nature. European Examples of Transboundary Conservation. Gland, Switzerland and Belgrade, Serbia: IUCN Programme Office for South-Eastern Europe.

Vasilijević, M., Zunckel, K., McKinney, M., Erg, B., Schoon, M., Rosen Michel, T. (2015). Transboundary Conservation: A systematic and integrated approach. Best Practice Protected Area Guidelines Series No. 23, Gland, Switzerland: IUCN

WHC (2019). The Operational Guidelines for the Implementation of the World Heritage Convention. WHC.19/01. July 2019.

WHC (1994). The Operational Guidelines for the Implementation of the World Heritage Convention. WHC/2/Revised. February 1994.

Westing, A. H. (1998). Establishment and Management of Transfrontier Reserves for Conflict Prevention and Confidence Building. Environmental Conservation 25 (2): 91-94.

Wongwaiwit, F. (2009). Transboundary Cooperation for Architectural Heritage Management, Case Study: Phra Wiharn World Heritage Site. (Unpublished Master Thesis), Silpakorn University.

Zbicz, D.C. (1999a). Transboundary Co-operation in Conservation: A Global Survey of Factors Influencing Co-operation between Internationally Adjoining Protected Areas. (Unpublished Ph.D. Dissertation). Duke University, USA.

Zbicz, D.C. (1999b). Nature of Transboundary Cooperation. Environment, $41,15-16$. 